\title{
SIETE VO VZDELÁVANÍ: MOŽNOSTI VYUŽITIA ANALÝZY SOCIÁLNYCH SIETÍ V PEDAGOGICKOM VÝZKUME
}

\author{
NETWORKS IN EDUCATION: \\ MAKING USE OF SOCIAL NETWORK \\ ANALYSIS IN EDUCATIONAL RESEARCH
}

\author{
TOMÁŠ LINTNER
}

\begin{abstract}
Abstrakt
Analýza sociálnych sietí si svojim širokým využitím nachádz̧a miesto v množstve vedeckých odborov. $\checkmark$ pedagogickom výskume má potenciál odhalit’ a preskúmat' doteraz neznáme usporiadania vat'ahov medzi aktérmi vo vzdelávaní. Tento článok poskytuje úvod do problematiky, techník a využitia analýzy sociálnych sieti v pedagogickom výskume. V prvom rade predstavije základnú terminológiu a koncepty analýzy sociálnych sietí. Na príklade malej siete ilustruje základné siet’ové výpoćty tak na úrovni jednotlivých aktérov, ako na úrovni celej siete. Clánok d’alej poskytuje stručný prebl’ad śtúdii z.pedagogickébo výskumu, $v$ ktorých bola analýza sociálnych sietí využitá. Hlavná čast' článku na priklade fiktivnej triedy a piatich výskumných otázok ukazuje možnosti analýzy sociálnych sieti v pedagogickom výskume od základnej prierezovej analýzy po dynamickú inferenčnú analýzu. Krok za krokom sú predstavené rôzne metódy s následnou interpretáciou ich výsledkov. Okrem výpočtov centralit, klastrovacieho koeficientu a prepojenosti siete sú v prikladoch predstavené aj permutačné testy pri testovani významnosti za využitia sietových dát, ERGM (exponential random graph models) a STERGM (separable temporal exponential graph models). $\checkmark$ neposlednom rade sú prediskutované problémy spojené s využitím analýzy sociálnych sietí.
\end{abstract}

\section{Kl'účové slová}

SNA, analýra sociálnych sieti, komplexné siete, metodológia v pedagogickom výskume, modely sociálnych sieti, ERGM

\footnotetext{
Abstract

With its wide range of applications, social network, analysis has found its place in a number of scientific fields. In educational research, social network analysis has the potential to uncover and investigate yet unknown configurations of relationships among actors in education. This paper provides an introduction to the issues, techniques, and applications of social network analysis in educational research. It first surveys the basic
} 
terminology and concepts in social network analysis. Using the example of a small network, it demonstrates basic network calculations at the level of both the individual actors and the network as a whole. Furthermore, the paper provides a brief overview of studies in the field of educational research that have employed social network analysis. Using the example of a fictional classroom and five research questions, the main part of the paper demonstrates the application of social network analysis in educational research ranging from crosssectional descriptive analysis to dynamic inferential analysis. Step by step, it introduces a range of methods and interprets their results. In addition to centrality, clustering, and connectedness measures, the example contains permutation tests used for significance testing with network data, exponential random graph models (ERGM), and separable temporal exponential graph models (STERGM). Finally, the paper discusses challenges related to the application of social network analysis.

\section{Keywords}

social network analysis, SNA, complex networks, methodology in educational research, social network. models, ERGM

\section{Úvod}

Zatial' čo v prírodných vedách panuje široký konsenzus, že skúmané fenomény vieme vedeckými metódami odmerat', vzt’ahy medzi nimi modelovat', naše modely experimentálne overit' a dostat' sa tak k objektívnej pravde, v sociálnych vedách sa ujala škála epistemiologických pozícií, ktoré viac alebo menej spochybňujú možnosti sociálnych vied realisticky popísat' fenomény sociálneho sveta. Jed nou z najčastejších výhrad je fakt, že sociálne fenomény sú tak komplexné a navzájom prepojené, že odmerat' a popísat' všetky ich súčasti je prakticky nemožné. Čo však sociálne vedy robit' môžu a robit' by mali, je využit' dostupné prostriedky a prinášat' nové zistenia, ktoré ak aj nebudú odrážat' objektívnu pravdu, budú sa k nej aspoň približovat' (Radford, 2008). Analýza sociálnych sietí (social network analysis - SNA) má potenciál takýmto prostriedkom byt' a na množstvo fenoménov sociálneho sveta priniest' nový - realistickejší pohl'ad. SNA prináša možnosti pojat' prepojenost' sociálneho sveta a preklenút' hranice medzi správaním jednotlivcov, správaním skupín a správaním spoločnosti tým, že berie v úvahu nielen existenciu a typ vzt’ahov medzi jednotlivcami, ale celú štruktúru vzt’ahov a polohu jednotlivcov v týchto štruktúrach (Borgatti et al., 2009).

Siet' je v analýze sociálnych sietí štruktúra pozostávajúca z aktérov a väzbami medzi aktérmi (obrázok 1). Vzhl’adom na to, že sociálne procesy sú spôsoby, akými jednotlivci, skupiny a inštitúcie interagujú; spôsoby, akými väzby medzi aktérmi vznikajú a zanikajú (Shibutani, 2000), tieto procesy sú zo svojej podstaty zakorenené v sociálnych štruktúrach, ktoré sa koncept sociálnych sietí snaží uchopit' a poskytnút' výskumný rámec pre ich analýzu (Scott, 2017). Koncept sociálnych sietí bol začlenený do teórie sociálneho kapitálu (Lin, 2017) či teórie sociálnej kontroly (Daldal, 2014) a najmä vd’aka 
technologickému vývoju umožňujúcemu komplexné štatistické analýzy za posledných pät'desiat rokov rádovo vzrástol záujem o analýzu sociálnych sietí ako aj publikované štúdie s jej využitím (Knoke \& Yang, 2020; Wasserman \& Faust, 2019).

V kontexte pedagogického výskumu môže siet' reprezentovat' širokú škálu akérov a väzieb medzi nimi. Od najmenších sociálnych štruktúr vo vzdelávaní vo forme žiakov, učitelov, rodičov a vzt'ahov medzi nimi, po makro-štruktúry na úrovni škôl, krajín či vzdelávacích politík. SNA má v pedagogickom výskume potenciál rozšírit' doterajšie poznanie tým, že umožňuje skúmat', merat' a testovat', ako sú aktéri vo vzdelávaní a vzt’ahy medzi nimi usporiadané.

Tento článok je úvodom do problematiky analýzy sociálnych sietív pedagogických vedách. Článok si kladie za ciel’ predstavit' analýzu sociálnych sietí, uviest' príklady jej využítia v existujúcom pedagogickom výskume a na sérii praktických príkladov ilustrovat' jej možnosti. Nejedná sa o článok zachádzajúci do detailov špecifikácie jednotlivých modelov, o manuál analytických softvérov ani o vyčerpávajúcu prehl’adovú štúdiu využitia analýzy sociálnych sietí. Článok ničmenej intenzívne odkazuje tak na teoretické štúdie, ktoré dali metódam používaným v tomto článku podobu, ako aj na praktické manuály pre uživatelov jednotlivých softvérov či príklady dobrej praxe. Napriek tomu, že článok sa zameriava na využitie analýzy sociálnych sietí v pedagogickom výskume, metódy preberané v článku sú aplikovatelné pre široké spektrum sociovedného výskumu.

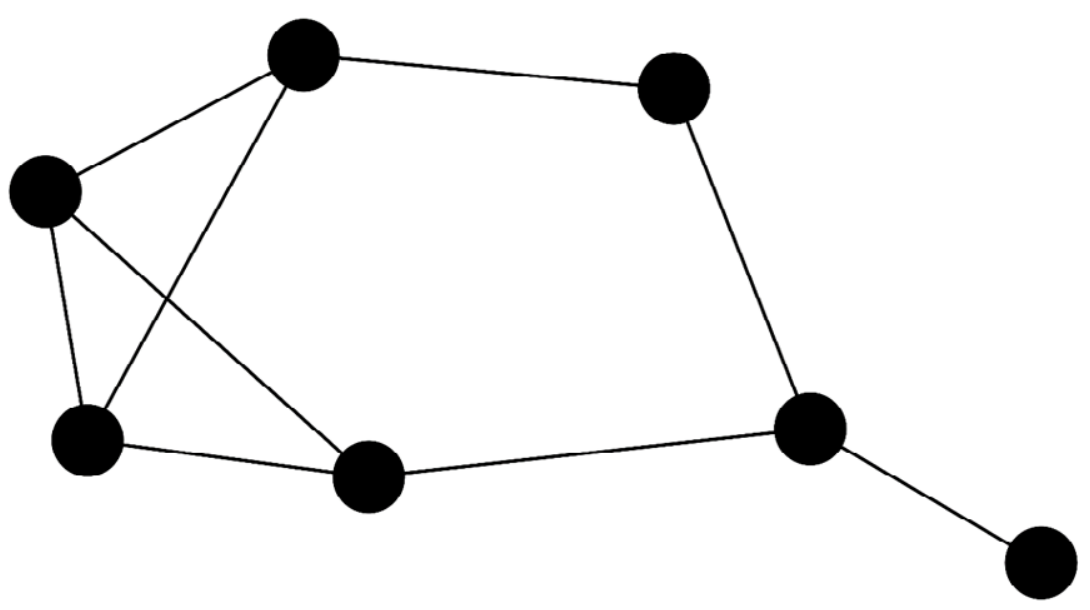

Obrázok 1

Ilustrácia siete - kruby znázorñujú aktérov, čiary väzby medzi aktérmi 


\section{Základy analýzy sociálnych sietí}

Analýza sociálnych sietí (social network analysis - SNA) je súhrn metód založených na teórii grafov, algebry a priestorových analýz (Scott, 2012). SNA umožňuje nahliadat' na sociálne štruktúry a komplexné vzt'ahy tak, aby verne reflektovali reálnu podobu sociálnych sietí vo svete (Wasserman \& Faust, 2019). Súčasná podoba SNA je ovplyvnená práve štrukturálnym prístupom v sociologickom výskume, ktorý stavia úlohu sociálnych štruktúr a ich vplyv na aktérov v spoločnosti do popredia záujmu. Napriek tomu, že stavia na princípoch Morenovej sociometrie (Moreno, 1934) a Whiteovej relačnej sociológie (White, 2008), pridáva k nim princípy využitia systematického zberu empirických dát a využitia matematických modelov na skúmanie štrukturálnych procesov (Freeman, 2004). SNA otvára možnosti sociálne štruktúry vierohodne merat', vysvetl'ovat' spôsoby, ako vznikli, a vysvetl'ovat' ich vplyv na jednotlivých aktérov v rámci sociálnych sietí (Knoke \& Yang, 2020). Súčasná podoba SNA so širokou škálou softvérov umožňuje tak deskriptívne a exploratórne analýzy, ako aj inferenčné siet’ové modely, spolu so širokými možnost’ami zobrazovania sociálnych sietí.

Hlavnými prvkami SNA sú vrcholy reprezentujúce aktérov v sociálnej sieti a hrany reprezentujúce vzt'ahy medzi aktérmi. Spojenia môžu byt' orientované (directed), v prípade, že záleží na smere spojenia - napríklad vrchol $\mathrm{N} 1$ môže prechovávat' sympatie k vrcholu N2, vrchol N2 už ale nie k vrcholu N1; alebo neorientované (undirected), v prípade, že na smere spojenia nezáleží, sociálna siet' reprezentuje iba existenciu vzájomného spojenia. Okrem samotných vrcholov a hrán sú v SNA často dôležité aj vlastnosti (attributes) jednotlivých vrcholov a hrán. Vlastnosti vrcholov môžu byt' tak kategorické - napríklad pohlavie aktérov, ako numerické - napríklad vek aktérov. V prípade, že sa jedná o vlastnosti hrán, rozlišujeme medzi hranami binárnymi - hrana bud' existuje, alebo nie, a váženými - hrana má okrem svojej existencie d'alšie vlastnosti, ktoré môžu byt' tak numerické - napríklad počet hodín, ktorý spolu dvaja aktéri strávili, ako kategorické - napríklad typ vzt’ahu medzi aktérmi. 
$[[1,2],[1,3],[2,1],[2,3]$,

$[3,1],[3,2],[3,4],[4,3]$,

$[4,5],[5,4],[5,6],[5,7]$,

$[7,5],[7,6],[8,7],[9]]$

Obrázok 2

Matica susednosti (vlavo) a zoznam hrán (vpravo) siete X1

Sociálna siet' je v SNA reprezentovaná maticou susednosti (adjacency matrix) alebo zoznamom hrán (edge list). Matica susednosti zobrazuje vzt’ahy medzi aktérmi siete $\mathrm{v}$ dvojdimenznom rozložení, zatial čo zoznam hrán zobrazuje zoznam vzt'ahov medzi aktérmi siete. Väčšina SNA softvérov vie spracovat' dáta z oboch typov reprezentácíi a rozdiel je iba vo forme zdrojových dát. Zatial' čo matica susednosti vie byt' intuitívnejšia a sama o sebe prezradit' základnú štruktúru siete, zoznam hrán vie byt' užitočnejší pri siet’ach s vel'kým počtom vrcholov, kde by matica susednosti nadobudla neprakticky vel'ké rozmery ${ }^{1}$. Obrázok 2 zobrazuje maticu susednosti 9 x 9 orientovanej siete, kde hodnota 1 reprezentuje prítomnost' a hodnota 0 neprítomnost' vzt'ahu spolu so zoznamom hrán tej istej siete, kde pri sebe uvedené vrcholy majú medzi sebou hranu.

Obrázok 3 zobrazuje orientovanú siet’ $X 1$ vytvorenú z predošlej matice susednosti (resp. zoznamu hrán) s 9 vrcholmi N1 až N9, 15 binárnymi hranami, z ktorých 12 tvorí 6 vzájomných hrán a 3 hrany sú jednosmerné ([N8, N7], [N7, N6], [N5, N6]). 8 vrcholov je vzájomne prepojených $\mathrm{v}$ jednom komponente (skupina vzájomne prepojených vrcholov) a jeden vrchol (N9) je izolovaný. Predstavme si, že naša siet' reprezentuje 9 l’udí a ich komunikačné kanály. Graf je orientovaný, čo znamená, že nie každá hrana znamená vzájomnú komunikáciu. Zatial' čo informácia od N8 sa vie dostat' ku každému okrem N9, informácia od N1 sa nedostane ani k N9, ani k N8, ked’že N8 informácie neprijíma. Základnými výpočtami štrukturálnych vlastností siete sa budeme snažit' identifikovat' najvplyvnejšie vrcholy, nájst' v rámci siete podskupiny a posúdit' prepojenost' siete.

Scott (2017) a Carrington et al. (2009) do detailov rozoberajú rozdielne prístupy $\mathrm{k}$ dátam v SNA vrátane zberu dát. 


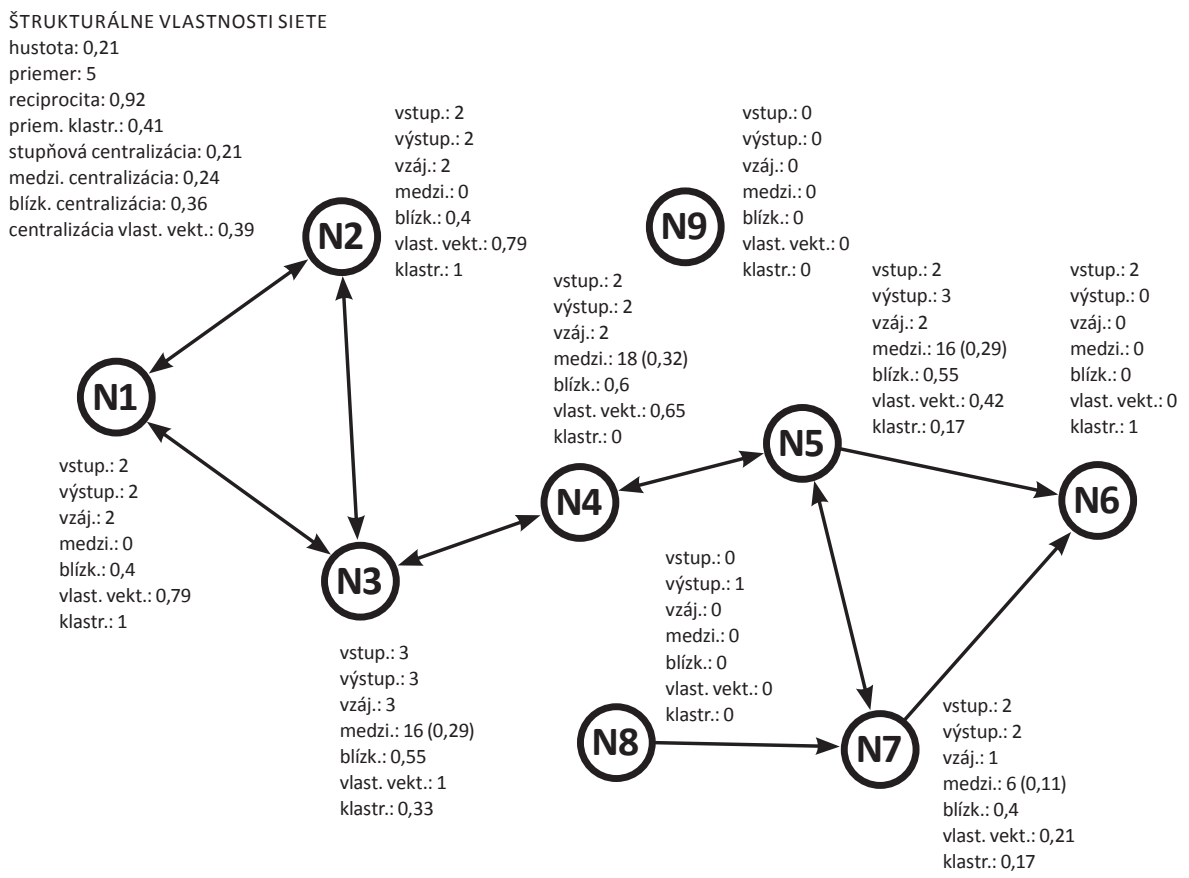

Obrázok 3

Zobrazenie siete X1 so zák.ladnými štrukturálnymi premennými

Položme si otázku: kto je v sieti najvplyvnejší? Kto vie najviac ovplyvnit' tok informácií? Ak by sme nevideli štruktúru siete, odpoved' by pravdepodobne znela N3, ked’že šíri a rovnako tak prijíma informácie od najväčšieho počtu ludí ( $\mathrm{n}=3)$. Ked' sa však na štruktúru siete pozrieme, uvidíme, že v závislosti toho, ako koncept vplyvu uchopíme, N4 má potenciál byt' nemenej vplyvný než N3, a to napriek tomu, že má o jednu vzájomnú väzbu menej. Jedným z klúčových konceptov SNA je výpočet centrality vrcholov. Výpočty centralít sa snažia odhalit' relatívny vplyv vrcholov v sieti na základe ich polohy v sieti (Bonachich, 1987; Borgatti, 2005). Existujú desiatky výpočtov centralít a každá z nich koncept vplyvu berie inak. Neexistuje jeden výpočet centrality, ktorý jednoznačne odpovie na otázku, ktoré vrcholy sú v sieti najvplyvnejšie. Každá z centralít meria niečo iné, preto je prospešné vziat' do úvahy rôzne výpočty centralít a je na výskumníkovi, aké závery z hodnôt centralít urobí. Hodnoty centralít počítame vždy pre jeden komponent, všetky nasledujúce príklady sú preto počítané pre komponent $\mathrm{s} 8$ vrcholmi bez izolovaného vrcholu ${ }^{2}$.

Pre teoretický základ výpočtu centralít pozri Friedkin (1991), pre detailný prehlad výpočtov centralít a ich aplikácie pozri Landherr et al. (2010) a Valente et al. (2008). 
Najjednoduchším a najzákladnejším výpočtom centrality je stupeñ (degree centrality), ktorý meria počet väzieb vrcholu. $\mathrm{V}$ prípade orientovaných sietí sa jedná o vstupný stupeñ (in-degree) s počtom hrán, ktoré smerujú $\mathrm{k}$ danému vrcholu, a výstupný stupeň (out-degree) s počtom hrán, ktoré smerujú od daného vrcholu. Výpočet centrality na základe hodnoty stupňa je založený na myšlienke, že vyšší počet väzieb umožňuje väčšie možnosti priamo ovplyvňovat' ostatných aktérov, prípadne získavat' priamo informácie od väčšieho množstva aktérov. V sieti $X 1$ má najväčšiu hodnotu vstupného stupňa vrchol N3 (3), ktorý má zároveň spolu s vrcholom N5 najväčšiu hodnotu výstupného stupňa (3).

Iným typom centrality je medril'ablost' (betweenness centrality), ktorá meria počet najkratších ciest (geodesic paths), ktoré cez daný vrchol prechádzajú od všetkých ostatných vrcholov ku všetkým ostatným vrcholom. Medzil’ahlost' je mimoriadne dôležitá pri identifikácii vplyvu aktérov na tok komunikácie, prípadne inej výmeny medzi aktérmi, kde je dôležitá najkratšia vzdialenost' medzi vrcholmi. Odráža vplyv aktéra na základe toho, akú úlohu zohráva ako most medzi ostatnými aktérmi v rámci siete (Freeman, 1977). Ak by sa v sieti X1 vrchol N4 rozhodol zadržat' tok informácií, žiadne neposielat' d’alej a štruktúra siete by zostala nezmenená, ovplyvnil by tým 18 informačných kanálov v sieti, zatial' čo ak by sa rovnako zachoval N3, ovplyvnil by ich iba 16. Napriek tomu, že N3 má vyššiu hodnotu tak vstupného, ako aj výstupného stupňa, N4 má väčší potenciál ovplyvnit’ tok informácii medzi ostatnými vrcholmi. N4 je najvplyvnejším mostom v sieti, cez ktorý prechádza najväčší počet informácíi. ${ }^{3}$

Ak chceme vziat' do úvahy vzdialenosti, ktoré informácie musia prejst' od jedného vrcholu k ostatným, budeme počitat' blį̧́ost' (clossenness centrality) vrcholu. Blízkost' podobne ako medzil’ahlost' využíva na určenie vplyvu najkratšie vzdialenosti medzi vrcholmi. Blízkost’ však vyjadruje to, ako blízko má daný vrchol k ostatným nezávisle od toho, či cez neho prechádzajú najkratšie cesty ostatných vrcholov. Je počítaná priemernou dížkou najkratších vzdialeností daného vrcholu k ostatným (Sabidussi, 1966) - na obrázku 3 normalizovaná do hodnoty $0-1$, kde hodnota 1 značí najkratšie vzialenosti a najvyššiu hodnotu blízkosti. V sieti X1 má najvyššiu hodnotu blízkosti vrchol N4 (0,6), a teda je z ostatných vrcholov v priemere najbližšie k ostatným. $\mathrm{V}$ neposlednom rade centralita vlastnébo vektora (eigenvector centrality) meria vplyv vrcholu s predpokladom, že pre vrchol nie je dôležitý priamo jeho vlastný vplyv, ale vplyv vrcholov tesne pri ňom. Vysoká hodnota centrality vlastného

Hodnota polohovej centrality sa dá, podobne ako pri ostatných centralitách, normalizovat' do hodnoty 0-1 (na obrázku 3 v zátvorkách). 
vektora naznačuje, že vrchol má spojenia s inými vrcholmi, ktoré majú sami vysoké hodnoty centrality vlastného vektora (Bonachich, 1987; 2007). Inými slovami, vrchol s vysokou hodnotou centrality vlastného vektora bude mat' potenciál ovplyvnit’ ostatných aktérov v sieti cez vrcholy, s ktorými má priame väzby. V sieti X1 má najvyššiu hodnotu centrality vlastného vektora vrchol N3.

Okrem prominentných vrcholov je prospešné identifikovat' v sieti podskupiny $-\mathrm{v}$ najširšom slova zmysle definované ako vrcholy, ktoré majú medzi sebou v porovnaní so zvyškom siete hustejšie väzby. Podskupiny v sieti sú charakteristické tým, že vo vnútri majú medzi sebou silné prepojenia, no s vrcholmi mimo podskupiny sú spojené iba malým počtom väzieb. Z pohladu pedagogiky môžu podskupiny reflektovat' napríklad vrstevnícke skupiny, neformálne skupiny učitelov, alebo skupiny spolupráce pri kolaboratívnom učení. Najzákladnejším typom podskupiny je klika (clique), ktorá je definovaná ako súhrn vrcholov, kde každý vrchol má s ostatnými vrcholmi medzi sebou väzby, a jedná sa teda o úplný graf. V sieti X1 je úplná klika len jedna a pozostáva z troch vrcholov - N1, N2, N3. Okrem tejto kliky je v sieti aj neúplná klika medzi vrcholmi N5, N6, N7, kde vrchol N6 zvyšným dvom vrcholom vzt'ahy neopätuje. Tendencia združovat' sa do klík je vyjadrená klastrovacím koeficientom (clustering coefficient), ktorý vyjadruje pomer väzieb susediacich vrcholov, ktoré vedú k ostatným vrcholom, s ktorými má daný vrchol väzby. Hodnota klastrovacieho koeficientu 1 značí, že vrchol má väzby iba s takými vrcholmi, ktoré majú zároveň väzby medzi sebou. ${ }^{4} \mathrm{Z}$ pohl’adu celej siete je možné určit' tendenciu združovat' sa do klík priemerným klastrovacim koeficientom (average clustering coefficient), ktorý je vypočítaný ako priemer klastrovacích koeficientov vrcholov v sieti. Hodnota klastrovacieho koeficientu siete X1 0,41 naznačuje, že v priemere skoro polovica väzieb vedie k takým vrcholom, ktoré majú zároveň väzby medzi sebou. ${ }^{5}$

$\mathrm{Na}$ úrovni siete je okrem priemerného klastrovacieho koeficientu dôležitá aj jej prepojenost'. Čím je siet' prepojenejšia, tým budú k sebe vrcholy bližšie a tým jednoduchšie (príp. rýchlejšie) bude v sieti prebiehat' tok informácíi. Medzi základné výpočty prepojenosti siete patria hustota siete (network density) vypočítaná ako pomer existujúcich väzieb k všetkým možným väzbám,

Pre rozsiahlejší text o klikách pozri Wasserman a Faust (2019).

Pokročilejšími metódami identifikácie podskupín v sieti sú algoritmy na detekciu podskupín v sieti (community detection algorithms), ktoré vedia byt' užitočné najmä pri vel'kých alebo hustých siet’ach, kde na identifikáciu podskupín nestačia základné siet’ové výpočty (Fortunato, 2010). 
ktoré by v sieti mohli vzniknút'; priemer siete (network diameter) vypočítaný ako najkratšia vzdialenost' medzi dvoma najvzdialenejšími vrcholmi; centralizácia siete (network centralization) vyjadrujúca, ako vel'mi je siet' postavená okolo malého počtu centrálnych aktérov, vypočítaná na základe špecifického typu centrality; a v orientovaných siet’ach tiež reciprocita (reciprocity) vypočítaná ako pomer väzieb v sieti, ktoré sú vzájomné. Na úrovni vrcholov je reciprocita vyjadrená bud' počtom vzájomných (na obrázku 3) väzieb, alebo pomerom opätovaných väzieb. Hustota siete $X 1$ je 0,21 a jej priemer 5 (vzdialenost' medzi vrcholmi N8 a N1) pri počte vrcholov 9 naznačuje, že siet' je relatívne málo prepojená. Pre ilustráciu sú pre siet' vypočítané hodnoty centralizácie pre všetky hore uvedené typy centralít s hodnotou od 0,21 pre stupňovú centralizáciu po 0,39 pre centralizáciu vlastného vektora. Hodnoty centralizácií nenaznačujú vel'kú tendenciu vrcholov zoskupovat' sa okolo centrálnych aktérov. Hodnota reciprocity 0,92 naznačuje, že väčšina hrán je vzájomných.

\section{SNA v pedagogickom výskume}

Zatial' čo metódy založené na sociometrii sú ako v česko-slovenskom (Nagy et al., 2018; Kalkusová, 2017; Šalamounová \& Fučík, 2019; Titmanová, 2019; Vítová et al., 2013), tak vo svetovom (Barclay, 1967; Baron, 1951; Cerezo \& Ato, 2005; Kindermann, 2007; Leung \& Silberling, 2006; Peery, 1979) pedagogickom výskume pomerne zaužívané, metódy založené na analýze sociálnych sietí za využitia matematických modelov sú využívané zriedka a začali sa objavovat' iba nedávno. V nasledujúcej časti odkazujem na príklady využitia SNA v existujúcom pedagogickom výskume.

Niekol'ko autorov využilo SNA pri skúmaní dynamiky tvorby vzt’ahov medzi žiakmi na úrovni triedy. Výskum v inkluzívnych predprimárnych triedach tímu Chen et al. (2019) preukázal segregáciu detí s postihnutím a menšie rozmery sociálnych sietí detí s postihnutím v porovnaní s det'mi bez postihnutia. Štúdia tímu Anderson et al. (2016) naznačuje, že kombinácia vel’kosti triedy a pohlavia žiakov má vplyv na sociálnu pozíciu žiakov s poruchami autistického spektra $\mathrm{v}$ inkluzívnych triedach. Zaradenie do väčších tried malo pre chlapcov s týmto spektrom negatívny vplyv na tvorbu ich sociálnych sietí. Štúdia tímu Jiao et al. (2017) naznačuje, že vrstevnícke skupíny na druhom stupni môžu mat' vplyv na subjektívny pocit blaha žiakov, kde žiaci v rámci vrstevnických skupín vykazovali podobné pocity. Huitsing a Veenstra (2012) využili blok modelovanie pri identifikácii podskupín agresorov pri výskume šikany v triede. Analýza sociálnych sietí adolescentov na amerických školách tímu Goodreau et al. (2009) preukázala efekty selektívneho výberu (homofílie) na základe pohlavia a etnika. Zatial čo všetky sledované etniká 
preukazovali preferencie tvorby vzt’ahov s vlastným etnikom, černosi a ázijci vykazovali efekt homofílie najviac. Podobné výsledky prináša aj štúdia Lubbers (2003), ktorá skúmala štruktúru sociálnych sietí medzi žiakmi v triede a medzi triedami v sekundárnom vzdelávaní v Holandsku. Jej výskum preukázal preferencie žiakov vytvárat' vzt’ahy so žiakmi s rovnakým pohlavím, etnickým pôvodom a spoločnou skúsenost’ou v predošlom vzdelávaní. V neposlednom rade Snijders a Baerveldt (2003) výskumom sociálnych väzieb na holandských stredných školách preukázali, že žiaci preukazujú tendencie k homofílii na základe delikventného správania.

Ďalší autori zas využili SNA pri výskume interakcií medzi študentmi. Bokhove (2018) ukazuje využitie SNA pri výskume interakcií v rámci školskej triedy. Han et al. (2016) preukázali rastúcu tendenciu kolaboratívnej siete pri záverečnom projekte online predmetu univerzitného pregraduálneho štúdia. Podobne Naim et al. (2010) pri výskume vývoja interakcií v prezenčnom kolaboratívnom učení študentov univerzitného postgraduálneho štúdia zaznamenali rastúcu tendenciu sietí študentov. Štúdia tímu Stepanyana et al. (2010) na druhú stranu naznačuje postupom času rastúcu tendenciu univerzitných online študentov interagovat' so spolužiakmi selektívnejšie - s čoraz menším počtom spolužiakov. Jimoyiannis et al. (2013) využili SNA na skúmanie hlavných aktérov $v$ skupinách kolaboratívneho online učenia. Autori zistili, že participácia na kolaboratívnom učení viedla k efektívnej integrácii ich myšlienok v skupine. Štúdia d’alej preukázala, že skupiny mali tendenciu vytvorit' relatívne centralizované siete okolo malého počtu aktívnych študentov.

Niekol'ko autorov využilo SNA na skúmanie učitel’ských vzt’ahov a spolupráce. Meijs a De Laat (2012) preukázali dôležitost' neformálnych vzt’ahov medzi učitel’mi na ich profesijný rozvoj na základných školách. Autori argumentujú, že najvplyvnejší učitelia sú klučoví pri zavádzaní nových učebných postupov. K podobným záverom prišla štúdia Quardokusa a Hendersona (2015), ktorá skúmala štruktúru neformálnych vzt’ahov na univerzitných katedrách. Štúdia tímu Bakkenesa et al. (1999) zas naznačuje, že učitelia na základných školách sa združujú podl’a svojej špecializácie, a preukazuje dôležitost' spájajúcich článkov - učitel'ov, ktorí tvoria mosty medzi jednotlivými podskupinami učitelov. Za zmienku stoja aj exploratórne analýzy publikačných sietí výskumníkov z pedagogickej oblasti (Juhaňák, 2017; Munoz et al., 2016).

Na úrovni škôl, organizácií či krajín bola SNA využitá taktiež. Breuer et al. (2009) zozbierali dáta z učitel'ského kolaboratívneho projektu éTwinning zo 45000 škôl z celej Európy. Skúmali štyri úrovne spolupráce - medzi učitel’mi, školami, projektami a krajinami. Štúdia preukázala, že väčšina registrovaných škôl a učitelov bola v projekte neaktívna. Ďalej preukázala vysokú 
mieru centralizácie a malú mieru prepojenosti sietí, čo malo za dôsledok, že väčšina učitelov nebola prepojená s jadrom siete a mala limitovaný prístup k informáciam. Kolleck (2015) využila SNA na výskum implementácie vládnych opatrení v oblasti školstva v Nemecku. Jej štúdia na základe výpočtov centralít preukázala, že mimovládne organizácie a vládni aktéri mali ovel’a vplyvnejšie postavenie pri implementácii opatrení než školy samotné.

\section{Metódy SNA v praxi}

V nasledujúcej časti ilustrujem využitie, aplikáciu a interpretáciu SNA v pedagogickom výskume na sérii 5 výskumných otázok za použitia orientovanej sociálnej siete $X 2$ reprezentujúcej fiktívnu školskú triedu (obrázok 4). Pôvodné dáta zahŕňajú okrem matice susednosti mená, pohlavie, status žiaka so špeciálnymi vzdelávacími potrebami (ŠVP) a vážený prospech normalizovaný do hodnoty $0-1$, kde hodnota 0 značí najhorší a hodnota 1 najlepší prospech v triede. V triede je 26 žiakov - 13 dievčat (50\%) (tmavá farba vrcholov), 13 chlapcov (50\%) (svetlá farba vrcholov); z toho 10 žiakov $(38,46 \%)-$ 4 dievčatá $(15,38 \%)$ a 6 chlapcov (23,08 \%) - má špeciálne vzdelávacie potreby - ŠVP (biela farba názvu vrcholov). Hrany reprezentujú sympatie - v prípade vzájomných sympatí môžeme väzbu vnímat' ako priatel'stvo. Vel'kost' vrcholov reprezentuje vstupný stupeň - kol'ko spolužiakov vyjadrilo danému žiakovi sympatie. Siet' je vizualizovaná v softvéri Gephi (Bastian et al., 2009) za využitia layoutu ForceAtlas2 (Jacomy et al., 2014). Siet'ové výpočty sú robené v Rknižnici statnet (Handcock et al., 2018; Hunter et al., 2008). Permutačné testy sú robené v Rknižnici RVAideMemoire (Hervé, 2020).

Výskumné otázky:

VO1: Liši sa sociálne postavenie žiakov so špeciálnymi vzdelávacimi potrebami $v$ triede od ostatných? (prierezová analýza s použitím permutačného t-testu)

VO2: Existuje súvislost' medzi centralitou vlastného vektora v rámci triedy a prospechom $v$ škole? (prierezová analýza za použitia Pearsonovho korelačného koeficientu s permutačným testom)

VO3: Ovplyvñuje homofilia na základe poblavia a statusu žiaka so ŠVP podobu sociálnej siete v triede? (prierezová analýza za použitia ERG modelu)

VO4: Ako sa vyvíjala sociálna siet’ v triede v čase? (deskriptívna dynamická analýza)

VO5: Co ovplyvnilo tvorbu sociálnej siete v triede v čase? (dynamická analýza za použitia STERG modelu) 


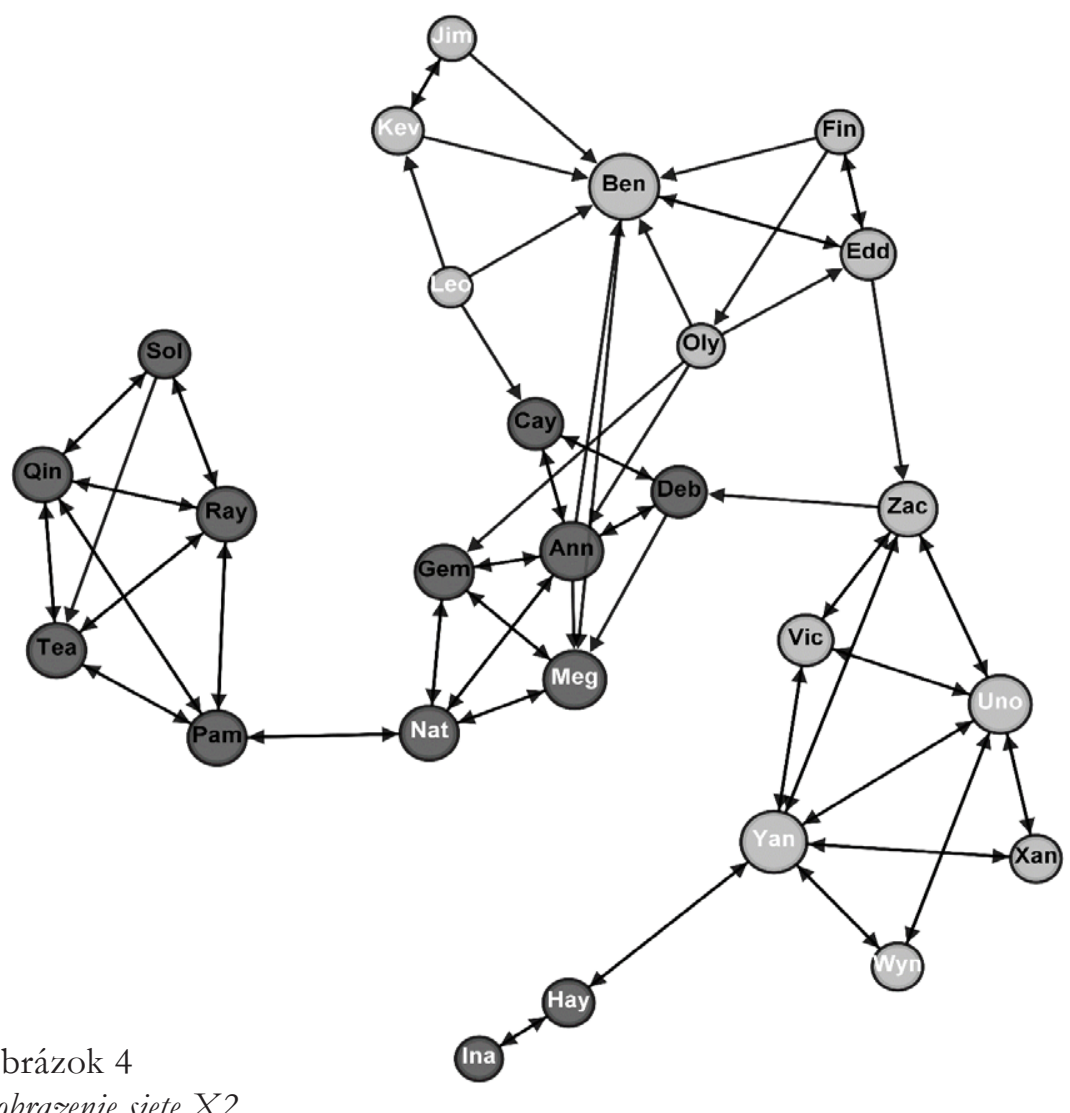

Zobrazenie siete X2

VO1: Liši sa sociálne postavenie žiakov so špeciálnymi vądelávacimi potrebami v triede od ostatných?

Prvú výskumnú otázku bude adresovat’ prierezová analýza za použitia výpočtu základných štrukturálnych vlastností siete a permutačného t-testu․ Aby sme na otázku odpovedali, je potrebné vypočítat' hodnoty štrukturálnych premenných všetkých žiakov. Tabul'ka 1 zobrazuje deskriptívnu štatistiku siete na úrovni vrcholov siete $X 2$. Pohl’adom na jednotlivých žiakov zistíme,

6 Medzi používané SNA softvéry umožňujúce výpočty základných vlastností siete patria Rknižnica statnet (Handcock et al., 2018; Hunter et al., 2008), Gephi (Bastian et al., 2009), Pajek (Batagelj \& Mrvar, 1998), igraph (Csárdi \& Nepusz, 2006) či UCINET (Borgatti et al., 2002). Pre manuály pozri: statnet (Butts, 2008; Butts \& Butts, 2019; Goodreau et al., 2008), Gephi (Cherven, 2013; Cherven, 2015; Gephi.org, 2017), Pajek (Mrvar \& Batagelj, 2019), igraph (Csárdi \& Nepusz, 2010), UCINET(UCINET, 2020). 
že vel'ká čast' žiakov so ŠVP má nízke hodnoty vstupných a výstupných stupňov, nulové hodnoty klastrovacieho koeficientu a nulové hodnoty medzilahlosti, čo môže naznačovat', že žiaci so ŠVP sa menej socializujú a oproti ostatným sa menej združujú do klík. Tieto hodnoty sa dajú interpretovat' rôzne, a ak by sme mali prístup do triedy, určite by bolo zaujímavé napríklad pozriet' sa kvalitatívnym dizajnom na správanie sa žiakov s nízkymi hodnotami štrukturálnych premenných $\mathrm{v}$ triede ${ }^{7}$. My však chceme s využitím SNA dospiet' k záveru o rozdieloch medzi dvoma skupinami žiakov; preto rozdelíme žiakov do dvoch skupín - ŠVP a bez ŠVP a vypočítame aritmetické priemery so smerodatnými odchylkami (SD) štrukturálych hodnôt oboch skupín (tabul'ka 2). Namerané priemery naznačujú, že žiaci so ŠVP majú všetky hodnoty štrukturálnych premenných nižšie než žiaci bez ŠVP.

Ak však chceme $z$ našich dát urobit' záver o rozdieloch medzi žiakmi bez ŠVP a žiakmi so ŠVP, potrebujeme vykonat' test významnosti, na základe ktorého budeme alebo nebudeme môct' odmietnut' nulovú hypotézu, že rozdiely v nameraných štrukturálnych premenných medzi žiakmi boli spôsobené náhodou. Štandardným postupom by v tomto prípade bol nepárový t-test. Štandardný t-test však pri počítaní $p$ hodnoty predpokladá vzájomnú nezávislost' všetkých pozorovaných hodnôt. Siet’ové premenné však majú zo svojej podstaty medzi sebou dyadické závislosti - hodnoty vzájomných väzieb, klastrovacieho koeficientu či centralít sú všetky závislé na vstupných a výstupných stupňoch všetkých ostatných vrcholov. Ak by sme zmenili počet väzieb jedného vrcholu, ov plyvnilo by to hodnoty štrukturálnych premenných všetkých ostatných vrcholov. Testy predpokladajúce vzájomnú nezávislost' pozorovaných premenných sú preto pri siet'ových dátach nepoužitelné.

Alternatívou sú testy významnosti založené na permutácii dát, ktoré nie sú založené na predpoklade nezávislosti pozorovaní. Permutačné testy vel'kým množstvom simulácií sledujú možné rozdelenie výsledkov pozorovaní zo súboru sledovaných premenných a porovnávajú ich s empirickým výsledkom. ${ }^{8}$ Permutačné testy sú používané tiež pri modelovaní za použitia siet’ových dát. Pri modelovaní vel'kosti efektu sa používajú bežné nástroje inferenčnej štatistiky ako testy korelácie či regresné modely, sú však doplnené o testy významnosti založené na permutácii dát. Špeciálnymi typmi permutačných testov využívaných v SNA sú aj CUG test (conditional uniform graph test) a QAP

SNA môže byt' relevantnou súčast'ou zmiešaného výzkumného dizajnu. Kvalitatívny dizajn vie SNA obohatit' o dôležité premenné, zatial čo SNA vie kvalitatívny dizajn obohatit' o pohl'ad na sledované štruktúry (Edwards, 2010; Martinez et al., 2003).

$8 \quad$ Pre obsiahlejší výklad permutačného testu pozri kapitolu 8.2 v Borgatti et al. (2018). Pre teóriu za permutačnými testami pozri Berry et al. (2019) a Butts (2007). 
test (quadriatic assignments procedure test). Zatial' čo CUG test necháva pri permutáciách jednu štrukturálnu premennú rovnakú a mení štruktúru siete, QAP test necháva pri permutácii celú štruktúru siete nezmenenú. CUG test je preto vhodný na testovanie významnosti štrukturálnych premenných jednej siete, zatial' čo QAP test je vhodný na testovanie významnosti medzi siet’ami (Cunningham et al., 2016)9.

Tabul'ka 1

Deskriptivna statistika siete X2 na úrovni urcholov

\begin{tabular}{|c|c|c|c|c|c|c|c|c|c|c|}
\hline žiak & pohl. & ŠVP & prosp. & vstup. & výstup. & vzáj. & klastr. & medzi. & blízk. & $\begin{array}{c}\text { vlast. } \\
\text { vek. }\end{array}$ \\
\hline Ann & D & $\mathrm{N}$ & 0,25 & 5 & 6 & 4 & 0,33 & 0,37 & 0,33 & 0,66 \\
\hline Ben & $\mathrm{CH}$ & $\mathrm{N}$ & 0,42 & 7 & 2 & 1 & 0,25 & 0,36 & 0,32 & 0,31 \\
\hline Cay & D & $\mathrm{N}$ & 0,52 & 3 & 2 & 2 & 0,40 & 0,01 & 0,26 & 0,33 \\
\hline Deb & D & $\mathrm{N}$ & 0,05 & 3 & 3 & 2 & 0,40 & 0,19 & 0,26 & 0,49 \\
\hline Edd & $\mathrm{CH}$ & $\mathrm{N}$ & 0,91 & 3 & 3 & 2 & 0,53 & 0,32 & 0,34 & 0,15 \\
\hline Fin & $\mathrm{CH}$ & $\mathrm{N}$ & 0,85 & 1 & 3 & 1 & 0,83 & 0,04 & 0,31 & 0,06 \\
\hline Gem & Ď & $\mathrm{N}$ & 0,27 & 4 & 3 & 3 & 0,67 & 0,03 & 0,28 & 0,67 \\
\hline Hay & Ď & A & 0,32 & 2 & 2 & 2 & 0,00 & 0,08 & 0,22 & 0,29 \\
\hline Ina & D & A & 0,12 & 1 & 1 & 1 & 0,00 & 0,00 & 0,18 & 0,08 \\
\hline $\mathrm{Jim}$ & $\mathrm{CH}$ & A & 0,00 & 1 & 2 & 1 & 0,67 & 0,00 & 0,29 & 0,01 \\
\hline $\mathrm{Kev}$ & $\mathrm{CH}$ & A & 0,12 & 2 & 2 & 1 & 0,50 & 0,00 & 0,26 & 0,01 \\
\hline Leo & $\mathrm{CH}$ & A & 0,05 & 0 & 3 & 0 & 0,33 & 0,00 & 0,29 & 0,00 \\
\hline Meg & D & A & 0,95 & 5 & 2 & 2 & 0,48 & 0,12 & 0,23 & 0,85 \\
\hline Nat & Ď & A & 0,93 & 4 & 4 & 4 & 0,43 & 0,33 & 0,29 & 0,83 \\
\hline Oly & $\mathrm{CH}$ & $\mathrm{N}$ & 0,23 & 1 & 4 & 0 & 0,50 & 0,01 & 0,35 & 0,02 \\
\hline Pam & D́ & $\mathrm{N}$ & 0,96 & 4 & 4 & 4 & 0,43 & 0,26 & 0,25 & 0,78 \\
\hline Qin & Ď & $\mathrm{N}$ & 0,78 & 4 & 4 & 4 & 0,71 & 0,03 & 0,21 & 0,68 \\
\hline Ray & Ď & $\mathrm{N}$ & 0,54 & 4 & 4 & 4 & 0,71 & 0,03 & 0,21 & 0,68 \\
\hline Sol & Ď & $\mathrm{N}$ & 0,42 & 2 & 3 & 2 & 0,80 & 0,00 & 0,18 & 0,37 \\
\hline Tea & Ď & $\mathrm{N}$ & 0,75 & 1 & 3 & 3 & 0,76 & 0,01 & 0,21 & 0,68 \\
\hline Uno & $\mathrm{CH}$ & A & 1,00 & 5 & 5 & 5 & 0,32 & 0,06 & 0,27 & 0,94 \\
\hline Vic & $\mathrm{CH}$ & $\mathrm{N}$ & 0,80 & 3 & 3 & 3 & 0,83 & 0,00 & 0,27 & 0,72 \\
\hline Wyn & $\mathrm{CH}$ & A & 0,45 & 2 & 2 & 2 & 0,67 & 0,00 & 0,22 & 0,51 \\
\hline Xan & $\mathrm{CH}$ & $\mathrm{N}$ & 0,41 & 2 & 2 & 2 & 0,67 & 0,00 & 0,22 & 0,51 \\
\hline Yan & $\mathrm{CH}$ & A & 0,91 & 6 & 6 & 6 & 0,24 & 0,21 & 0,28 & 1,00 \\
\hline Zac & $\mathrm{CH}$ & $\mathrm{N}$ & 0,82 & 4 & 4 & 3 & 0,30 & 0,40 & 0,32 & 0,76 \\
\hline
\end{tabular}

Pre porovnanie a príklady CUG a QAP testov v R pozri Murphy (2020). 
Permutačný nepárový t-test s úrovňou významnosti $\alpha=0,05$ (tabul'ka 2) pri 10000 permutáciach dokázal v sieti X2 odmietnut' nulovú hypotézu iba pri klastrovacom koeficiente (tučným písmom). ${ }^{10} \mathrm{Naša} \mathrm{analýza} \mathrm{preukázala,} \mathrm{že}$ žiaci so ŠVP majú v porovnaní so žiakmi bez ŠVP menší klastrovací koeficient, čo naznačuje, že sa menej združujú v klíkách. V ostatných pozorovaných aspektoch sú si však dve skupiny žiakov podobné.

Tabul'ka 2

Priemery hodnôt premenných siete X2 na úrouni kategórii ŠV $P /$ bez Š $S P$

\begin{tabular}{|l|c|c|c|c|c|c|c|}
\hline & vstup. & výstup. & vzáj. & klastr. & medzi. & blízk. & $\begin{array}{c}\text { vlast. } \\
\text { vek. }\end{array}$ \\
\hline \multirow{2}{*}{ ŠVP priem. (SD) } & 2,80 & 2,9 & 2,4 & 0,36 & 0,08 & 0,25 & 0,45 \\
& $(2,04)$ & $(1,60)$ & $(1,96)$ & $(0,24)$ & $(0,11)$ & $(0,03)$ & $(0,42)$ \\
\hline \multirow{2}{*}{ bez ŠVP priem. (SD) } & 3,19 & 3,32 & 2,5 & 0,57 & 0,13 & 0,27 & 0,49 \\
& $(1,60)$ & $(1,01)$ & $(1,21)$ & $(0,20)$ & $(0,16)$ & $(0,05)$ & $(0,25)$ \\
\hline$p$ hodnota perm. t-testu & 0,6729 & 0,5139 & 0,9739 & $\mathbf{0 , 0 2 5}$ & 0,3925 & 0,3837 & 0,9699 \\
\hline
\end{tabular}

VO2: Existuje súvislost' medżi centralitou vlastného vektora v rámci triedy a prospechom $v$ škole?

Druhú výskumnú otázku bude adresovat' výpočet Pearsonovho korelačného koeficientu s permutačným testom. Výpočet preukázal pozitívny lineárny vzt'ah $(\varrho=0,6522 \mathrm{~s} p$ hodnotou $=0,001$ pri 10000 permutáciach $)$ medzi premennými centralitou vlastného vektora a prospechu v sieti X2. Výsledok naznačuje, že žiaci s vysokými hodnotami centrality vlastného vektora majú zároveň v porovnaní s ostatnými lepší prospech. Výpovedná hodnota koeficientu je však obmedzená na konštatovanie existencie pozitívneho vzt’ahu medzi dvoma premennými. Jednak výpočet neberie do úvahy iné premenné, ktoré môžu ovplyvňovat' prospech a centralitu vlastného vektora, jednak v prípade prierezových dát nie je možné definitívne určit’ smer závislosti - korelácia nám nehovorí, či vysoká hodnota centrality vlastného vektora vedie $\mathrm{k}$ lepšiemu prospechu, či prospech vedie $\mathrm{k}$ vysokej centralite vlastného vektora, alebo či sú obe premenné tak závislé ako nezávislé. ${ }^{11}$ Rovnako ako pri nesiet'ových dátach sa nemusíme obmedzovat' na výpočet korelačného koeficientu. $\mathrm{Na}$ modelovanie vzt’ahov s použitím siet’ových dát môžeme využit' všetky možnosti regresných modelov. Na posúdenie významnosti však musíme vždy použit' testy založené na permutácii.

\footnotetext{
$10 \quad$ Nastavenie úrovne významnosti pri testovaní nulovej hypotézy je komplexnou problematikou a zaužívané hodnoty by nemali byt' používané automaticky (Kim, 2015).

11 Pre dokazovanie kauzality pozri Beebee et al. (2009) a Heath et al. (1993).
} 
VO3: Ovplyvñuje homofilia na základe poblavia a statusu žiaka so ŠV P podobu sociálnej siete $v$ triede?

Zatial čo výpočty korelačného koeficientu a regresné modely sa využívajú na preukázanie a meranie vzt’ahov medzi premennými bez modelovania samotnej štruktúry siete, ERG modely (exponential random graph models známe aj ako $p^{*}$ models) sa za použitia prierezových dát snažia identifikovat' efekty, ktoré podobu sociálnej siete ovplyvňujú. ${ }^{12}$ ERG modely sú založené na myšlienke, že podoba siete je ovplyvnená množstvom navzájom sa prelínajúcich efektov na mikro úrovni. Efekty sú rôzne usporiadania väzieb, o ktorých je predpoklad, že sa v sieti vyskytujú viac alebo menej, než by sme očakávali náhodou. ERG modely vedia poňat' vel'ké množstvo efektov vrátane ich vzájomných závislostí a umožňujú tak realisticky modelovat' siet'ové štruktúry (Morris et al., 2008) ${ }^{13}$. Najväčším prínosom ERG modelov je práve ich schopnost' identifikovat' a oddelit' silu jednotlivých efektov v sieti. Na prvý pohlad sa môže napríklad zdat', že siet' je ovplyvnená efektom homofílie, po započítaní efektu tranzitivity (tendencia vytvárat' väzby s tým, s ktorým mám spoločného známeho) však môžme zistit', že efekt homofílie je v konečnom dôsledku nevýznamný a pozorované homofílne väzby sú viac dôsledkom tranzitivity než homofílie samotnej. Výsledky ERG modelov sú pravdepodobnosti, s akými sa vytvorí vzt’ah medzi dvoma vrcholmi v sieti na základe jednotlivých sledovaných efektov. Sila jednotlivých efektov je vo forme log. odds. (logaritmus šancí) ${ }^{14}$. V prípade, že je sila efektu vyššia, než by sme očakávali náhodou, môžme predpokladat', že daný efekt ovplyvnil podobu sledovanej siete. Lusher et al. (2012) a Harris (2013) do detailov pojednávajú o ERG modelovaní - od základnej charakteristiky, cez riziká spojené s modelmi, po praktické príklady ich využitia ${ }^{15}$

ERG modelovanie sa dá rozdelit' do troch hlavných častí. V prvom rade musí byt' do modelu vložená sociálna siet' tak, ako bola odpozorovaná. V našom prípade je to matica susednosti siete $X 2$ a zoznam vlastností vrcholov. $\mathrm{V}$ druhom rade sa špecifikujú parametre modelu; vkladáme do modelu efekty, pri ktorých predpokladáme, že majú vplyv na štruktúru siete. Pri špecifikácii parametrov modelu sa štandardne začína s efektom prepojenosti (edges), ktorý slúži ako ekvivalent intercept pri bežných regresných modeloch (Hunter et al., 2008); následne sa pridávajú ostatné efekty a porovnáva sa, či sa celková

12 Medzi použivané SNA softvéry umožňujúce inferenčné analýzy patrí okrem Rknižnice statnet a UCINETu aj Rknižnica RSiena (Ripley et al., 2020) a software PNet (Wang et al., 2009).

13 Pre špecifikácie ERG modelov pozri Robins et al. (2007), Anderson et al. (1999), Wasserman a Pattison (1996) a Frank a Strauss (1986).

14 Pre vzt’ahmedzi log. odds, odds a odds ratios pozri Grimes a Schulz (2008) a Borenstein et al. (2009).

15 Pre ERGM manuály pre statnet pozri Goodreau et al. (2008) a Hunter et al. (2008). 
pravdepodobnost' modelu zlepšila. Najčastejšími efektami, ktoré sa pri špecifikácii ERG modelov používajú, sú pri orientovaných siet’ach okrem efektu prepojenosti efekty vzájomnosti (tendencia opätovat' jednosmerné väzby a tvorit' vzájomné väzby), tranzitivity (tendencia združovat' sa do klík), distribúcie stupňov (frekvencia, s akou sa v sieti vyskytujú jednotlivé hodnoty stupňov) a homofílie (tendencia vytvárat' vzt’ahy s vrcholmi s podobnými vlastnost’ami).${ }^{16}$ Tieto efekty boli popísané v mnohých štúdiách a ich vplyv je v sociálnych siet’ach považovaný za univerzálny (Kadushin, 2012). V našej sieti sa zameriame na všetky spomínané efekty s homofíliou na základe pohlavia a statusu žiaka so ŠVP.

Posledným a najdôležitejším krokom ERG modelovania je diagnostika modelu. Z ERG modelov môžu vzíst' hodnoverne vyzerajúce výsledky, ktoré sú ničmenej chybné a ich chybovost' je nutné skontrolovat' za použitia diagnostických postupov. Jedná sa o kontrolu konvergencie modelu (model convergence) a kontrolu dobrej zhody s dátami (goodness of fit). Kontrola konvergencie modelu má za ciel posúdit', či je model dostatočne špecifikovaný a odhady parametrov modelu sú spol’ahlivé. ERG modely zväčša využívajú pri odhadovaní parametrov modelu MCMC (Markov chain Monte Carlo) metódy. Ak odhady parametrov nie sú spolahlivé, hovoríme o degenerácii modelu (model degeneracy). Na druhú stranu kontrola dobrej zhody s dátami má za ciel’ posúdit', či je model kvalitný a špecifikovaný tak, že je schopný adekvátne reprodukovat' výsledky pozorovanej siete. Bez konvergencie modelu a zároveň dobrej zhody s dátami nie sú výsledky ERG modelov validné. ${ }^{17}$

Než prejdeme na interpretáciu výsledkov ERG modelu, musíme sa presvedčit' o konvergencii modelu a dobrej zhode s dátami. V knižnici statnet sa konvergencia modelu posudzuje po vytvorení modelu príkazom momc.diagnostics, ktorý vytvorí sériu modelov s našou špecifikáciou a sleduje hodnoty pozorovaných efektov. Ak model zkonvergoval, hodnoty všetkých efektov budú oscilovat' okolo priemernej hodnoty efektu pozorovanej siete. Hodnoty efektu prepojenosti v simulovaných siet’ach oscilujú okolo priemeru (obrázok 5). Ostatné hodnoty efektov vyzerajú podobne, čo naznačuje, že model zkonvergoval. ${ }^{18}$

16 Robins a Lusher v kapitole 13 v Lusher et al. (2012) rozoberajú základné špecifikácie rôznych typov sietí. Pre detaily špecifikácie parametrov v knižnici statnet pozri Morris et al. (2008).

$17 \quad$ Koskinen a Snijders v kapitole 12 v Lusher et al. (2012) vysvetl'ujú procesy pri ERG modelovaní vrátane diagnostiky. Pre diagnostiku modelov v knižnici statnet pozri Goodreau et al. (2008) a Li a Carriere (2013).

18 Neuvádzam grafy pre všetky sledované efekty, sú však k dispozícii na vyžiadanie. Ak sú ERG modely súčast'ou publikovaného výskumu, je dôležité, aby boli výsledky testu konvergencie bud' priložené priamo v štúdii, alebo aspoň k dispozícii na vyžiadanie. Rovnaké pravidlo platí aj pri testovaní dobrej zhody s dátami. 

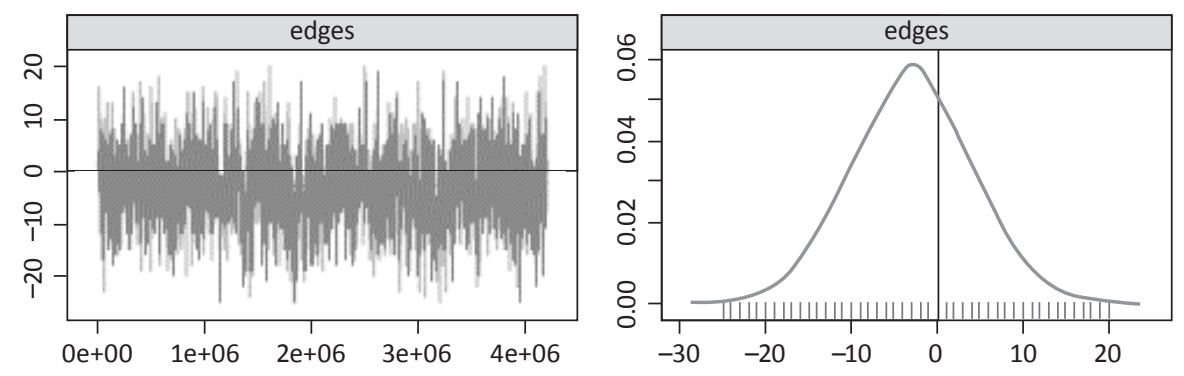

Obrázok 5

Graf distribúcie hodnôt efektu prepojenosti z.MCMC simulácií

Dobrá zhoda s dátami sa v knižnici statnet posudzuje príkazom gof, ktorý z množstva simulovaných sietí náhodne vyberie vzorku a porovnáva hodnoty štrukturálnych premenných vzorky s odpozorovanou siet’ou. Sledujú sa hodnoty vstupných a výstupných stupňov, tranzitivity, minimálne geodetické vzdialenosti, ako aj všetky efekty v modely. Výsledkom testu sú priemery hodnôt zo simulovaných sietí a $\not$ hodnoty vypočítané z porovnania priemerov hodnôt zo simulovaných sietí a reálne odpozorovanej siete. Č́m sú priemery hodnôt zo simulácií bližšie k hodnotám odpozorovanej siete a čím je $p$ hodnota vyššia, tým kvalitnejší model je. Všetky hodnoty priemerov zo simulovaných sietí sa blížia $\mathrm{k}$ hodnotám z odpozorovanej siete. $\mathrm{V}$ tabul'ke 3 sú uvedené $p$ hodnoty z testu (MC p-value), ktoré ukazujú vysokú mieru zhody. ${ }^{19}$

Výsledky nášho ERG modelu ${ }^{20}$ (tabul'ka 3) naznačujú, že štruktúra sociálnej siete X2 je ovplyvnená efektami vzájomnosti, tranzitivity, homofílie na základe pohlavia, ako aj homofílie na základe statusu žiaka s ŠVP. Všetky tieto efekty ovplyvnili podobu siete pozitívne, žiaci teda majú tendenciu

19 Neuvádzam $p$ hodnoty štrukturálnych premenných mimo sledovaných efektov ani hodnoty priemerov, sú však k dispozícii na vyžiadanie.

20 Náš model použil jednu jednoúrovňovú siet's jednoduchými väzbami, MCMC (Markov chain Monte Carlo) výpočtom závislosti a gwesp štatistikou (Snijders et al., 2006) pre výpočet tranzitivity. ERG modely však na túto konkrétnu špecifikáciu niesú odkazané. Pre porovnanie výpočtov závislostí v ERG modeloch pozri Lubbers a Snijders (2007). Pre príklady viacúrovňových modelov pozri Wang et al. (2013) a An (2015). Pre modely s váženými vzt’ahmi pozri Krivitsky (2012). Pre príklady curved ERGM, pozri Hunter a Handcock (2006). Pre príklady agregovania výsledkov z viacerých sietí pozri Lubbers (2003) a Chen et al. (2019). Pre rozvinutejšie úvahy pozri Van der Pol (2017), prípadne kapitolu 12 v Lusher et al. (2012). 
väzby opätovat', majú tendenciu vytvárat' vzt’ahy so spolužiakmi, s ktorými majú spoločného priatel'a, chlapci dávajú prednost' väzbám s chlapcami, dievčatá väzbám s dievčatami, žiaci s ŠVP s ostatnými žiakmi so ŠVP a žiaci bez ŠVP s ostatnými žiakmi bez ŠVP. Z týchto efektov je najsilnejší efekt vzájomnosti, nasledovaný efektami tranzitivity a homofílie na základe pohlavia s podobnou vel'kost'ou efektu a efektom homofílie na základe statusu žiaka s ŠVP. Ostatné efekty nie sú štatisticky významné. Za štatisticky významné sa štandardne považujú tie efekty, ktorých hodnota je aspoň dvakrát väčšia ako smerodajná chyba, prípadne ich hodnota $\operatorname{Pr}(>|z|)$ je menšia ako úroveň významnosti. ${ }^{21}$ Znamená to, že žiadna zo sledovaných skupín žiakov, či už na základe pohlavia alebo statusu žiaka s ŠVP, nemá tendenciu vytvárat' vzt’ahy menej alebo viac než tá druhá (efekt pohlavia a ŠVP). Rovnako tak žiaci nemajú tendenciu centralizovat' sa a vytvárat' viac vzt’ahov so spolužiakmi s vysokými hodnotami stupňov (distribúcie stupňov). ${ }^{22}$

Tabul'ka 3

Výsledky ERG modelu siete X2

\begin{tabular}{|l|c|c|c|}
\hline & log. odds (SE) & $\operatorname{Pr}(>|z|)$ & $\begin{array}{c}\text { MC } \\
\text { p-value }\end{array}$ \\
\hline edges (celková prepojenost') & $-3,09525(1,50836)$ & $0,04016 *$ & 1,00 \\
\hline mutual (vzájomnost') & $3,60490(0,64779)$ & $<1 \mathrm{e}-04 * * *$ & 1,00 \\
\hline twopath (prepojenost' cez dve hrany) & $-0,39341(0,24563)$ & 0,10924 & 0,86 \\
\hline gwideg.fixed.1 (distribúcia vstupných stupňov) & $-1,28121(1,07015)$ & 0,23122 & 1,00 \\
\hline gwodeg.fixed.1(distribúcia výstupných stupňov) & $2,28399(1,74982)$ & 0,19180 & 0,94 \\
\hline gwesp.fixed.1 (tranzitivita) & $0,75666(0,16907)$ & $<1 \mathrm{e}-04 * * *$ & 0,84 \\
\hline gwdsp.fixed.1 (efekt nižšieho rádu tranzitivity) & $0,03844(0,24398)$ & 0,87482 & 0,84 \\
\hline nodematch.pohlavie (homofília) & $0,82143(0,25412)$ & $0,00123 * *$ & 0,94 \\
\hline nodematch.ŠVP (homofília) & $0,32737(0,14008)$ & $0,01943 *$ & 0,98 \\
\hline nodefactor.pohlavie.ch (efekt pohlavia) & $-0,06364(0,13799)$ & 0,64467 & 1,00 \\
\hline nodefactor.ŠVP.a (efekt ŠVP) & $-0,07185$ (0,16186) & 0,65709 & 1,00 \\
\hline Signif. codes: 0 ***'0,001 **’0,01 **0,05 '’0,1 '’1 & & & \\
\hline & & & \\
\hline
\end{tabular}

22 Gwdegree štatistika sa okrem potreby konvergencie používa aj na preukázanie tzv. „popularity effect“", ktorý sa prejavuje tendenciou aktérov vytvárat' vzt’ahy s aktérmi, ktorí majú vysokú hodnotu centrality, čo má za následok vysokú centralizáciu siete. Zároveň má za následok rozdelenie siete na jadro, v ktorom majú aktéri s vysokými hodnotami centrality množstvo väzieb medzi sebou, a perifériu, v ktorej sú väzby málo početné a vedú smerom k jadru. Kontraintuitívne, záporná hodnota efektu značí pozitívny efekt centralizácie. Názorne ukázané v softwary gwdegree (Levy, 2016). 
VO4: Ako sa vyvíjala sociálna siet'v triede v čase?

Doteraz sme našu siet' analyzovali iba z jedného pozorovania. Predstavme si však, že podobu siete X2 poznáme aj v d'alších momentoch v čase a rôzne podoby siete tak vieme porovnat'. Siet' v čase T1 bola odpozorovaná krátko po vzniku triedy, v časoch T2-T5 v dvojmesačných intervaloch a v čase T6 na konci školského roku a zároveň $\mathrm{v}$ podobe, ako sme ju poznali doteraz (obrázok 6). Štvrtú výskumnú otázku bude adresovat' deskriptívna dynamická analýza za použitia výpočtu základných štrukturálnych vlastností siete. Napriek tomu, že naša analýza sa bude venovat' iba vlastnostiam na úrovni siete, dynamické analýzy vedia, podobne ako ich prierezové ekvivalenty, sledovat' hodnoty štrukturálnych premenných aj na úrovni jednotlivých vrcholov.

Okrem už známych výpočtov hustoty, reciprocity a priemerného klastrovacieho koeficientu vypočítame aj počet komponentov a počet vzniknutých a zaniknutých väzieb medzi jednotlivými sledovanými obdobiami (tabul'ka 4). Zatial' čo reciprocita siete zostávala v čase nezmenená, hustota siete sa za rok 2,5násobila. Siet' bola na začiatku vel'mi málo prepojená, čo potvrdzuje aj počet štyroch oddelených komponentov, od polovice roka však už žiaci tvorili jeden komponent. Priemerný klastrovací koeficient postupne rástol tiež, čo naznačuje, že nové väzby žiaci smerovali skôr ku spolužiakom v ich blízkosti, ktorí už mali existujúci vzt’ah s ich známymi. Hodnoty vzniknutých a zaniknutých väzieb naznačujú dôležitý moment v čase medzi T3 a T4. V tomto období vzniklo 37 a zaniklo 42 väzieb, čo sú v porovnaní so zvyškom roka pomerne vysoké čísla. Je to zároveň jediné obdobie, ked' viac väzieb zaniklo, než vzniklo. Môžeme teda uvažovat', že v čase medzi T3 a T4 sa v triede udiali významné zmeny v rovesníckych vzt'ahoch.

Tabul'ka 4

Deskriptívna dynamická śtatistika siete X2

\begin{tabular}{|l|c|c|c|c|c|c|}
\hline & T1 & T2 & T3 & T4 & T5 & T6 \\
\hline hustota & 0,0477 & 0,08 & 0,1031 & 0,0954 & 0,1108 & 0,1262 \\
\hline počet komponentov & 4 & 1 & 2 & 1 & 1 & 1 \\
\hline reciprocita & 0,96 & 0,92 & 0,88 & 0,8831 & 0,92 & 0,9446 \\
\hline priemerný klastrovací koeficient & 0 & 0,042 & 0,111 & 0,088 & 0,242 & 0,488 \\
\hline vznik väzieb & $\mathrm{n} / \mathrm{a}$ & 24 & 22 & 37 & 22 & 25 \\
\hline zánik väzieb & $\mathrm{n} / \mathrm{a}$ & 3 & 7 & 42 & 12 & 15 \\
\hline
\end{tabular}



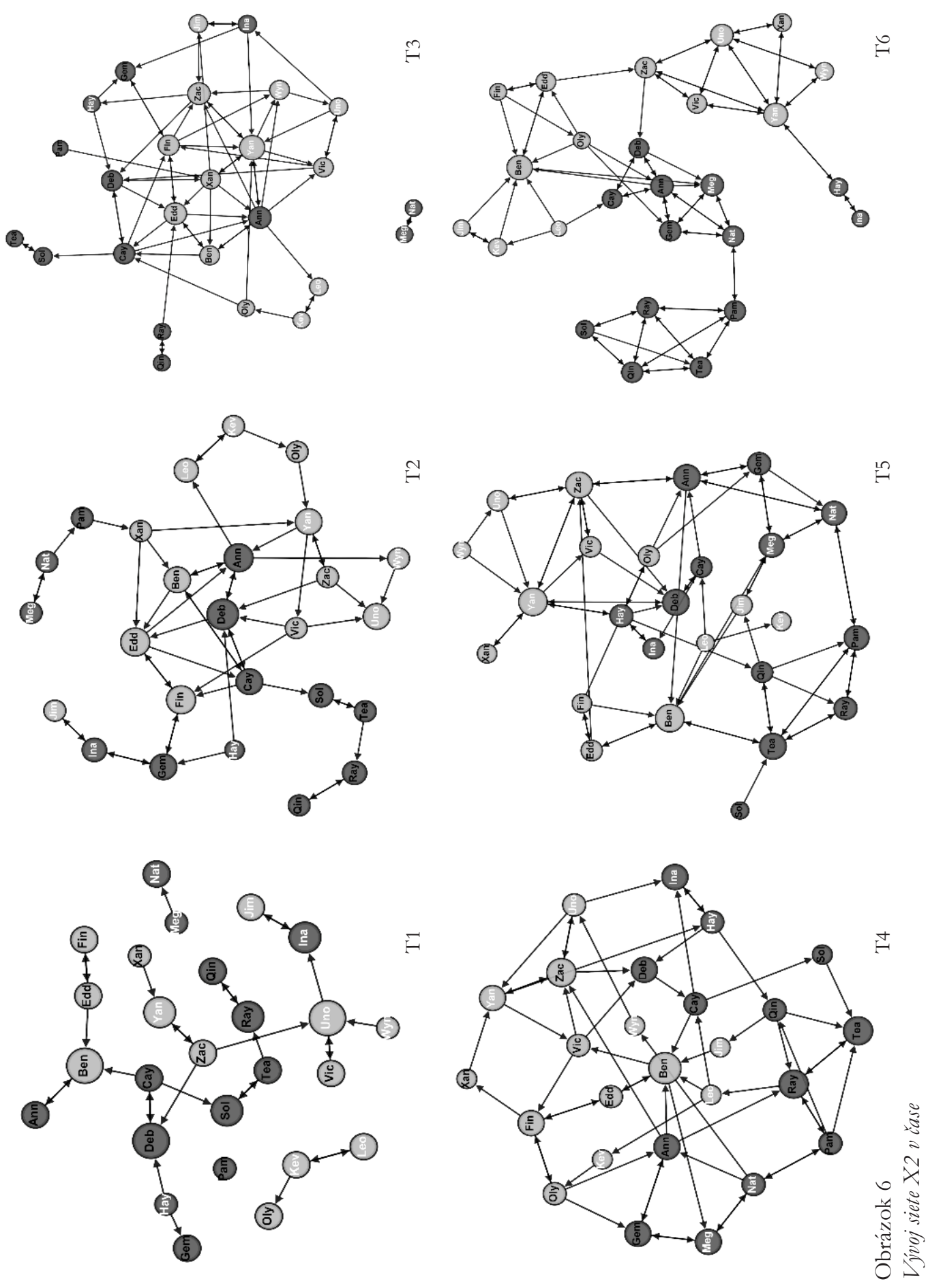
VO5: Co ovplyvnilo tvorbu sociálnej siete v triede v čase?

Piatu výskumnú otázku bude adresovat' STERG model (separable temporal exponential random graph model), ktorý je podobný ERG modelu, s rozdielom, že na preukázanie vplyvov ovplyvňujúcich podobu siete využíva dynamické dáta (Krivitsky \& Goodreau, 2019; Krivitsky \& Handcock, 2014). Postup STERG modelovania je taktiež podobný postupu ERG modelovania s rozdielom, že do modelu sa nevloží jedna siet', ale séria sietí tak, ako boli odpozorované. Rovnakým postupom sa špecifikujú efekty modelu, na rozdiel od ERG modelov však STERG modely počítajú silu efektov tak pre vznik, ako aj pre zánik väzieb a tieto efekty sa môžu špecifikovat' každé zvlášt'. Rovnako ako pri ERG modeloch prebieha testovanie konvergencie modelu a rovnako prebieha aj test dobrej zhody s dátami. ${ }^{23}$

Tabulka 5

Výsledky STERG modelu siete X2

\begin{tabular}{|l|c|c|c|}
\hline VZNIK VÄZIEB & $\log$. odds (SE) & $\operatorname{Pr}(>|z|)$ & $\begin{array}{c}\text { MC } \\
\text { p-value }\end{array}$ \\
\hline edges (celková prepojenost') & $-5,83946(0,67666)$ & $<1 \mathrm{e}-04 * * *$ & 1,00 \\
\hline mutual (vzájomnost') & $2,07775(0,23609)$ & $<1 \mathrm{e}-04 * * *$ & 1,00 \\
\hline twopath (prepojenost' cez dve hrany) & $0,13410(0,06223)$ & $0,031166 *$ & 0,98 \\
\hline gwideg.fixed.1 (distribúcia vstupných stupňov) & $1,12588(0,59917)$ & 0,060234, & 0,96 \\
\hline gwodeg.fixed.1 (distribúcia výstupných stupňov) & $2,32698(0,73244)$ & $0,001488 * *$ & 0,88 \\
\hline gwesp.fixed.1 (tranzitivita) & $0,43717(0,08273)$ & $<1 \mathrm{e}-04 * * *$ & 0,98 \\
\hline gwdsp.fixed.1 (efekt nižšieho rádu tranzitivity) & $-0,11456(0,08453)$ & 0,175318 & 0,98 \\
\hline nodematch.pohlavie (homofília) & $0,65748(0,17531)$ & $0,000177 * * *$ & 1,00 \\
\hline nodematch.ŠVP (homofília) & $0,35912(0,18348)$ & 0,050310 & 1,00 \\
\hline nodefactor.pohlavie.ch (efekt pohlavia) & $-0,06302(0,10065)$ & 0,531270 & 0,92 \\
\hline nodefactor.ŠVP.a (efekt ŠVP) & $-0,05813(0,13950)$ & 0,676903 & 1,00 \\
\hline ZÁNIK VÄZIEB & & & \\
\hline edges (celková prepojenost') & $-0,94288(0,89892)$ & 0,29422 & 1,00 \\
\hline mutual (vzájomnost') & $1,13590(0,36251)$ & $0,00173 * *$ & 0,98 \\
\hline twopath (prepojenost' cez dve hrany) & $0,57537(0,60277)$ & 0,33980 & 0,92 \\
\hline gwideg.fixed.1 (distribúcia vstupných stupňov) & $-0,50074(0,61642)$ & 0,41660 & 1,00 \\
\hline
\end{tabular}

23. Výsledky testu konvergencie sú k dispozícii na vyžiadanie. Rovnako ako pri ERG modely uvádzam $p$ hodnotu z testu dobrej zhody s dátami pri jednotlivých efektoch. 


\begin{tabular}{|l|c|c|c|}
\hline gwodeg.fixed.1 (distribúcia výstupných stupňov) & $1,57866(0,80234)$ & $0,04912 *$ & 0,98 \\
\hline gwesp.fixed.1 (tranzitivita) & $0,40846(0,20533)$ & $0,04667 *$ & 0,82 \\
\hline gwdsp.fixed.1 (efekt nižšieho rádu tranzitivity) & $-0,67815(0,62147)$ & 0,27518 & 0,90 \\
\hline nodematch.pohlavie (homofília) & $0,96630(0,30394)$ & $0,00148 * *$ & 0,96 \\
\hline nodematch.ŠVP (homofília) & $0,31971(0,32494)$ & 0,32516 & 1,00 \\
\hline nodefactor.pohlavie.ch (efekt pohlavia) & $-0,03357(0,18564)$ & 0,85651 & 0,98 \\
\hline nodefactor.ŠVP.a (efekt ŠVP) & $0,13078(0,22250)$ & 0,55668 & 1,00 \\
\hline Signif. codes: 0 '***'0,001 '**'0,01 '*'0,05 '’0,1 '’1 \\
\hline
\end{tabular}

Náš STERG model používa rovnakú špecifikáciu ako predošlý ERG model a rovnaké efekty sleduje tak pre vznik, ako aj pre zánik väzieb ${ }^{24}$ (tabul'ka 5). STERG model potvrdil významnost' všetkých efektov z ERG modelu pri tvorbe väzieb - efekty vzájomnosti, tranzitivity, homofílie na základe pohlavia, ako aj homofílie na základe statusu žiaka s ŠVP, aj ked' tento efekt sa pohybuje na hranici významnosti. Okrem spomínaných efektov však výsledky STERG modelu naznačujú aj pozitívny vplyv prepojenosti cez dve hrany a efekty distribúcie stupňov. Pri zániku väzieb model preukázal pozitívny vplyv efektu vzájomnosti, tranzitivity, homofílie na základe pohlavia, ako aj distribúcie výstupných stupňov.

Model ukazuje, že žiaci počas roka dávali prednost' tvorbe vzájomných väzieb, a ked’ väzby prerušili, bola tendencia väzby ukončit' vzájomne. Pozitívny efekt tranzitivity pri tvorbe ako aj pri zániku väzieb naznačuje, že žiaci dávali prednost' vzt’ahom vo väčších celkoch, a ked' väzby zanikali, zanikali tiež v rámci väčších celkov. Efekt homofílie na základe pohlavia tak pri tvorbe ako pri zániku väzieb zas naznačuje, že žiaci mali tendenciu nevy tvárat' väzby s opačným pohlavím, a preto aj ked' väzby zanikali, zanikali len v rámci homofílnych skupín. Model tiež ukazuje, že žiaci pri tvorbe vzt’ahov nedávali prednost' spolužiakom s vysokými hodnotami stupňov, a teda neprebiehala centralizácia. Rovnako ako pri ERG modely nemala žiadna zo sledovaných skupín žiakov, či už na základe pohlavia alebo statusu žiaka s ŠVP, tendenciu vytvárat' ani prerušovat' vzt'ahy viac alebo menej než tá druhá.

24 Pre detaily špecifikácie parametrov STERG modelov pozri Morris et al. (2019). 


\section{Ďalšie modely}

Okrem počítaných ERG a STERG modelov ponúka SNA využitie množstva d’alších modelov, ktoré prinášajú možnosti mimo ich rámca a napriek tomu, že v tomto článku nie sú ako súčast' praktických príkladov uvedené, majú potenciál pedagogický výskum obohatit’.

Blokmodely (Abbe, 2018; Holland et al., 1983; Wang \& Wong, 1983) sú postavené na koncepte ekvivalencie - siet' je možné zredukovat' na zjednodušenú verziu pozostávajúcu zo série pozíc (uskupenia aktérov) a rolí (väzbami medzi nimi), ktoré svojimi vlastnost’ami reprezentujú vlastnosti siete. Sú užitočné najmä pri porovnávaní vlastností viacerých sietí či pri vel'kých siet'ach, kde je žiadúce siet' pri zachovaní štrukturálnych vlastností zjednodušit'. ${ }^{25}$

Iným príkladom sú latentné priestorové modely (latent space models) (Hoff et al., 2005; Kim et al., 2018; Sarkar \& Moore, 2006; Sewell \& Chen, 2015; Sweet et al., 2013), založené na myšlienke, že aktéri v odpozorovanej sieti majú medzi sebou väzby, pretože sú pri sebe blízko v nízkorozmernom latentnom (nepozorovanom) priestore. Latentný priestor reprezentuje nepozorované atribúty, ktoré ničmenej ovplyvňujú podobu pozorovanej siete. Oproti ostatným modelom sú latentné priestorové modely vhodnejšie pri siet’ach so skrytými štruktúrami a/alebo množstvom chýbajúcich dát (Kim et al., 2018).

V neposlednom rade je potrebné spomenút' SAOM (stochastic actor-oriented models) (Burk et al., 2007; Snijders, 1996; Snijders et al., 2010), ktoré sú založené na rovnakom princípe ako ERG a STERG modely; predpokladajú, že podoba siete je ovplyvnená množstvom navzájom sa prelínajúcich efektov na mikro úrovni. Potenciálom SAOM je oddelit’ efekt sociálneho výberu od efektu sociálneho vplyvu (Steglich et al., 2010). Zatial’ čo efekt výberu je dôsledok konania jednotlivca na dynamiku siete, efekt vplyvu je dôsledok dynamiky siete na konanie jednotlivca. Príkladom efektu výberu je preferencia žiakov vytvárat' vzt'ahy so spolužiakmi s podobným prospechom. Na druhú stranu, efekt vplyvu je efekt skupiny spolužiakov na prospech žiaka. Oba efekty majú za dôsledok pozorovanú homofíliu na základe prospechu, v skutočnosti je však homofília výsledkom dvoch samostatných mechanizmov. SAOM využívajú dynamické dáta, a sú preto užitočné, ak máme siet’ové dáta vo viacerých časoch a chceme efekty sociálneho výberu a sociálneho vplyvu posudzovat' samostatne. $^{26}$

$25 \quad$ Pre dobrý úvod do blokmodelov pozri Diviák (2017).

26 Snijders et al. (2010) ilustrujú využitie SAOM pri štúdii dynamiky vzt’ahov v triede. 


\section{Problémy spojené s využitím SNA}

S množstvom možností, ktoré SNA vo výskume prináša, treba tiež spomenút' aj problémy a úskalia pri jej používaní. Tieto problémy plynú najmä z charakteru SNA, ked' siet'ové výpočty predpokladajú vzájomnú prepojenost' aktérov.

Vel'kým úskalím v SNA sú chýbajúce dáta, ktoré poznačujú siet’ové výpočty viac než iné - aj najmenšia zmena v sieti môže ovplyvnit' premenné ostatných aktérov (Kossinets, 2006). To znamená, že ak nám v sieti chýbajú aktéri, ktorí by tam však byt' mali, budú tým skreslené výpočty pre celú siet'. Toto platí špeciálne, ak nám chýbajú aktéri s prominentnou polohou v rámci siete - môžu nám chýbat' dôležité uzly, ktorých výpadok drasticky ovplyvní podobu siete. Rovnako tak sú mimoriadne ovplyvnené siete s malým počtom vrcholov, kde akákol’vek zmena v štruktúre je o to významnejšia. Okrem latentných priestorových modelov je pravdepodobne najspol’ahlivejším spôsobom, ako sa vysporiadat' s chýbajúcimi dátami v SNA, bezstratová imputácia, ked' sa hodnoty chýbajúcich premenných odvodia od nechýbajúcich premenných (Huisman, 2009).

Ďalším problémom je validita dát. Dáta používané v SNA sa väčšinou týkajú l’udí a vzt’ahov medzi nimi, čo dáta robí mimoriadne citlivými a ich zber mimoriadne náročným. Výskum Parkhursta a Hopmeyera (1998) napríklad preukázal významný rozdiel medzi popularitou v triede na základe sebahodnotenia a na základe hodnotenia spolužiakov. Rozdielne dáta tiež môžu priniest' rozdielne spôsoby zberu dát - Schofield et al. (1983) a Williams a Gilmour (1994) preukázali rozdiel medzi dátami o priatel’stvách v triede zozbieranými dvomi rozdielnymi metódami. Zatial čo dáta zozbierané spôsobom limitovaného výberu spolužiakov boli spol’ahlivejšie pri identifikácii blízkych priatel'stiev, dáta zozbierané spôsobom Likertovej škály s neobmedzeným výberom spolužiakov boli spol’ahlivejšie pri posudzovaní sociálnej pozície žiakov v rámci triedy. Pri zbere dát je preto potrebné zaistit' ich čo najväčšiu objektivitu a pri ich interpretácii vziat' do úvahy pôvod a charakter zozbieraných dát.

Úskalím je tiež časová náročnost’ SNA metód. Špeciálne SNA modelovanie si pri špecifikácii parametrov vyžaduje vel’kú dávku času a trpezlivosti. Jednak sa pri špecifikácii parametrov pracuje s vel'kým množstvom efektov a konvergencia a kvalita výsledných modelov musí byt' posúdená jednotlivo, jednak sú SNA modely náročné na výpočtovú pamät' a výkon počítača. Špeciálne pri vel'kých siet’ach sa môže výpočet jedného modelu pohybovat' v desiatkach minút až hodinách (Harris, 2013).

V neposlednom rade je potrebné spomenút' problémy s konvergenciou pri modelovaní za použitia odhadov parametrov modelu. Tento problém sa týka najmä ERG/STERG modelov. V súčasnosti sú za použitia algoritmov pre odhad parametrov ERG modely náchylné na degeneráciu a tento problém 
zatial’ nebol úplne odstránený. Problémy týkajúce sa degenerácie sa dajú minimalizovat' použitím gwesp štatistiky (Snijders et al., 2006), nie je však nezvyčajné, že aj ERG modely špecifikované podla dobrej praxe neskonvergujú a môžu byt' pre danú siet' nepoužitel'né (The Statnet Development Team, 2019).

\section{Záver}

V tomto článku bola predstavená analýza sociálnych sietí ako skupina metód založených na štúdiu sociálnych štruktúr a polohy aktérov v týchto štruktúrach, ktoré sa môžu stat'slubnou súčast'ou pedagogického výskumu. Vzdelávanie je od žiakov až po vzdelávacie politiky tvorené množstvami aktérov a vzt’ahov medzi nimi. Niekol'ko štúdií uvedených v článku dokazuje, že SNA sa dá v pedagogickom výskume aplikovat' od najmenších štruktúr $\mathrm{v}$ rámci triedy po štruktúry medzi krajinami. V hlavnej časti článku bol potenciál SNA ilustrovaný za využitia niekol'kých príkladov z fiktívnej školskej triedy a rovnako tak boli predstavené úskalia spojené s jej použitím. Napriek t’ažkostiam spojeným s potrebou kvalitných dát a časovou náročnost’ou vie byt' SNA užitočným nástrojom pri skúmaní vel'kého množstva procesov sociálneho sveta. S kvalitnými dátami sú možnosti SNA prakticky neobmedzené - môže slúžit' ako výstup sama o sebe, byt' súčast'ou exploratórnej analýzy, alebo súčast'ou zmiešaného dizajnu. Siet’ové modely vedia poňat' vel'ké množstvo efektov vrátane ich vzájomných závislostí a umožňujú tak realisticky modelovat' siet’ové štruktúry. Už aj najjednoduchšie výpočty za použitia SNA však vedia pedagogický výskum obohatit’ o cenné informácie. Bola by škoda to nevyužit’.

\section{Pod'akovanie}

Autor d’akuje dvom anonymným recenzentom, ktorých posudky nemalou mierou dopomohli k zvýšeniu kvality tohto článku.

\section{Literatúra}

Abbe, E. (2017). Community detection and stochastic block models: recent developments.

The Journal of Macbine Learning Research, 18(1), 6446-6531. https://doi.org/10.5555/3122009.3242034

An, W. (2015). Multilevel meta network analysis with application to studying network dynamics of network interventions. Social Networks, 43, 48-56. https://doi.org/10.1016/j. socnet.2015.03.006 
Anderson, A., Locke, J., Kretzmann, M., Kasari, C., \& AIR-B Network. (2016). Social network analysis of children with autism spectrum disorder: predictors of fragmentation and connectivity in elementary school classrooms. Autism, 20(6), 700-709. https://doi. org $/ 10.1177 / 1362361315603568$

Anderson, C. J., Wasserman, S., \& Crouch, B. (1999). A p* primer: Logit models for social networks. Social networks, 21(1), 37-66. https://doi.org/10.1016/S0378-8733(98)00012-4

Bakkenes, I., De Brabander, C., \& Imants, J. (1999). Teacher Isolation and Communication Network Analysis in Primary Schools. Educational Administration Quarterly, 35(2), 166-202. https://doi.org/10.1177/00131619921968518

Barclay, J. R. (1967). Effecting behavior change in the elementary classroom: An exploratory study. Journal of Counseling Psychology, 14(3), 240-247. https://doi.org/10.1037/h0024541

Baron, D. (1951). Personal-social characteristics and classroom social status: A sociometric study of fifth and sixth grade girls. Sociometry, 14(1), 32-42. https://doi.org/10.2307/2785208

Bastian, M., Heymann, S., \& Jacomy, M. (2009). Gephi: an open source software for exploring and manipulating networks. International A A AI Conference on Weblogs and Social Media. https://gephi.org/publications/gephi-bastian-feb09.pdf

Batagelj, V., \& Mrvar, A. (1998). Pajek - Program for Large Network Analysis. Connections, 21(2), 47-57. https://doi.org/10.1007/978-3-642-18638-7_4

Beebee, H., Hitchcock, C., \& Menzies, P. (Eds.). (2009). The Oxford Handbook of Causation. Oxford University Press. https://doi.org/10.1093/oxfordhb/9780199279739.001.0001

Berry, K. J., Johnston, J. E., \& Mielke, J. P. W. (2019). A Primer of Permutation Statistical Methods. Springer International Publishing. https://doi.org/10.1007/978-3-030-20933-9

Bokhove, C. (2018). Exploring classroom interaction with dynamic social network analysis. International Journal of Research \& Method in Education, 41(1), 17-37. https://doi.org/10.1080/ 1743727X.2016.1192116

Bonacich, P. (1987). Power and Centrality: A Family of Measures. American Journal of Sociology, 92(5), 1170-1182. https://doi.org/10.1086/228631

Bonacich, P. (2007). Some unique properties of eigenvector centrality. Social Networks, 29(4), 555-564. https://doi.org/10.1016/j.socnet.2007.04.002

Borenstein, M., Hedges, L. V., Higgins, J. P., \& Rothstein, H. R. (2009). Introduction to metaanalysis. John Wiley \& Sons. https://doi.org/10.1002/9780470743386

Borgatti, S. P. (2005). Centrality and network flow. Social Networks, 27(1), 55-71. https://doi. org/10.1016/j.socnet.2004.11.008

Borgatti, S. P., Everett, M. G., \& Freeman, L. C. (2002). Ucinet for Windows: Software for Social Network Analysis. Analytic Technologies.

Borgatti, S. P., Everett, M. G., \& Johnson, J. C. (2018). Analyzing social networks. SAGE.

Borgatti, S. P., Mehra, A., Brass, D. J., \& Labianca, G. (2009). Network analysis in the social sciences. Science, 323(5916), 892-895. https://doi.org/10.1126/science.1165821

Breuer, R., Klamma, R., Cao, Y., \& Vuorikari, R. (2009, September). Social network analysis of 45,000 schools: A case study of technology enhanced learning in europe. In European Conference on Technology Enhanced Learning (s. 166-180). Springer.

Burk, W. J., Steglich, C. E., \& Snijders, T. A. (2007). Beyond dyadic interdependence: Actor-oriented models for co-evolving social networks and individual behaviors. International journal of behavioral development, 31(4), 397-404. https://doi.org/10.1177/0165025407077762

Butts, C. T. (2007). 8. Permutation Models for Relational Data. Sociological Methodology, 37(1), 257-281. https://doi.org/10.1111/j.1467-9531.2007.00183.x 
Butts, C. T. (2008). Social network analysis with sna. Journal of statistical software, 24(6), 1-51. https://doi.org/10.18637/jss.v024.i06

Butts, C. T., \& Butts, M. C. T. (2019). Package 'sna'.

Carrington, P. J., Scott, J., \& Wasserman, S. (2009). Models and methods in social network analysis. Cambridge University Press.

Cerezo, F., \& Ato, M. (2005). Bullying in Spanish and English pupils: A sociometric perspective using the BULL-S questionnaire. Educational psychology, 25(4), 353-367. https://doi. org $/ 10.1080 / 01443410500041458$

Chen, J., Lin, T. J., Justice, L., \& Sawyer, B. (2019). The social networks of children with and without disabilities in early childhood special education classrooms. Journal of autism and developmental disorders, 1-16. https://doi.org/10.1007/s10803-017-3272-4

Cherven, K. (2013). Network graph analysis and visualization with Gephi: visualize and analyze your data swiftly using dynamic network, graphs built with Gephi. Packt Publishing.

Cherven, K. (2015). Mastering Gephi network visualization. Packt Publishing Ltd.

Csárdi, G., \& Nepusz, T. (2006). The igraph software package for complex network research. InterJournal, complex systems, 1695(5), 1-9.

Csárdi, G., \& Nepusz, T. (2010). igraph Reference manual. http://igraph. sourceforge. net/documentation. html

Cunningham, D., Everton, S., \& Murphy, P. (2016). Understanding dark networks: A strategic framework, for the use of social network analysis. Rowman \& Littlefield.

Daldal, A. (2014). Power and ideology in Michel Foucault and Antonio Gramsci: A comparative analysis. Review of History and Political Science, 2(2), 149-167.

Diviák, T. (2017). Ekvivalence a blokové modelování v analýze sociálních sítí. Naše společnost (Our Society), 15(1), 27-40. https://doi.org/10.13060/1214438X.2017.1.15.366

Edwards, G. (2010). Mixed-method approaches to social network analysis. National Centre for Research Methods.

Fortunato, S. (2010). Community detection in graphs. Physics reports, 486(3-5), 75-174. https:// doi.org/10.1016/j.physrep.2009.11.002

Frank, O., \& Strauss, D. (1986). Markov graphs. Journal of the american Statistical association, 81(395), 832-842. https://doi.org/10.2307/2289017

Freeman, L. C. (1977). A Set of Measures of Centrality Based on Betweenness. Sociometry, 40(1), 35-41. https://doi.org/10.2307/3033543

Freeman, L. C. (2004). The development of social network analysis. A Study in the Sociology of Science. Empirical Press.

Friedkin, N. E. (1991). Theoretical Foundations for Centrality Measures. American Journal of Sociology, 96(6), 1478-1504. https://doi.org/10.1086/229694

Gephi.org. (2017). Learn how to use Gephi. https://gephi.org/users/

Goodreau, S. M., Handcock, M. S., Hunter, D. R., Butts, C. T., \& Morris, M. (2008). A statnet Tutorial. Journal of statistical software, 24(9), 1-26. https://doi.org/10.18637/jss.v024.i09

Goodreau, S. M., Kitts, J. A., \& Morris, M. (2009). Birds of a feather, or friend of a friend? Using exponential random graph models to investigate adolescent social networks. Demography, 46(1), 103-125. https://doi.org/10.1353/dem.0.0045

Grimes, D. A., \& Schulz, K. F. (2008). Making sense of odds and odds ratios. Obstetrics \& Gynecology, 111(2), 423-426. https://doi.org/10.1097/01.AOG.0000297304.32187.5d 
Grund, T. U., \& Densley, J. A. (2015). Ethnic homophily and triad closure: Mapping internal gang structure using exponential random graph models. Journal of Contemporary Criminal Justice, 31(3), 354-370. https://doi.org/ 10.1177/1043986214553377

Han, G., McCubbins, O. P., \& Paulsen, T. H. (2016). Using Social Network Analysis to Measure Student Collaboration in an Undergraduate Capstone Course. NACTA Journal, 60(2), 176-182. https://lib.dr.iastate.edu/ageds_pubs/33/

Handcock, M., Hunter, D., Butts, C., Goodreau, S., Krivitsky, P., \& Morris, M. (2018). ergm: Fit, Simulate and Diagnose Exponential-Family Models for Networks. The Statnet Project (http:// www.statnet.org). R package version 3.9.4, https://CRAN.R-project.org/package=ergm

Harris, J. K. (2013). An introduction to exponential random graph modeling (Vol. 173). Sage Publications.

Heath, A. C., Kessler, R. C., Neale, M. C., Hewitt, J. K., Eaves, L. J., \& Kendler, K. S. (1993). Testing hypotheses about direction of causation using cross-sectional family data. Behavior Genetics, 23(1), 29-50. https://doi.org/10.1007/bf01067552

Hervé, M. (2020). Package 'RVAideMemoire'.

Hoff, P. D., Raftery, A. E., \& Handcock, M. S. (2002). Latent space approaches to social network analysis. Journal of the american Statistical association, 97(460), 1090-1098. https://doi. org/10.1198/016214502388618906

Holland, P. W., Laskey, K. B., \& Leinhardt, S. (1983). Stochastic blockmodels: First steps. Social networks, 5(2), 109-137. https://doi.org/10.1016/0378-8733(83)90021-7

Huisman, M. (2009). Imputation of missing network data: Some simple procedures. Journal of Social Structure, 10(1), 1-29. https://doi.org/10.1007/978-1-4614-7163-9_394-1

Huitsing, G., \& Veenstra, R. (2012). Bullying in classrooms: Participant roles from a social network perspective. Aggressive behavior, 38(6), 494-509. https://doi.org/10.1002/ab.21438

Hunter, D. R., \& Handcock, M. S. (2006). Inference in curved exponential family models for networks. Journal of Computational and Graphical Statistics, 15(3), 565-583. https://doi. org/10.1198/106186006X133069

Hunter, D., Handcock, M., Butts, C., Goodreau, S., \& Morris, M. (2008). ergm: A Package to Fit, Simulate and Diagnose Exponential-Family Models for Networks. Journal of Statistical Software, 24(3), 1-29. https://doi.org/10.18637/jss.v024.i03

Jacomy, M., Venturini, T., Heymann, S., \& Bastian, M. (2014). ForceAtlas2, a continuous graph layout algorithm for handy network visualization designed for the Gephi software. PloS one, 9(6). https://doi.org/10.1371/journal.pone.0098679

Jiao, C., Wang, T., Liu, J., Wu, H., Cui, F., \& Peng, X. (2017). Using Exponential Random Graph Models to analyze the character of peer relationship networks and their effects on the subjective well-being of adolescents. Frontiers in psychology, 8, 583. https://doi.org/10.3389/ fpsyg.2017.00583

Jimoyiannis, A., Tsiotakis, P., \& Roussinos, D. (2013). Social network analysis of students' participation and presence in a community of educational blogging. Interactive Technology and Smart Education, 10(1), 15-30. https://doi.org/10.1108/17415651311326428

Juhaňák, L. (2017). Sociální sítě autorů publikujících v pedagogických vědách v letech 2009-2013: Exploratorní analýza. Studia paedagogica, 22(1), 9-36. https://doi.org/10.5817/ SP2017-1-2

Kadushin, C. (2012). Understanding social networks: Theories, concepts, and findings. OUP USA.

Kalkusová, L. (2017). Adaptační kurz jako nástroj změny sociálních vztahů ve třídním kolektivu. Studia sportiva, 11(1), 128-134. https://doi.org/10.5817/StS2017-1-30 
Kindermann, T. A. (2007). Effects of Naturally Existing Peer Groups on Changes in Academic Engagement in a Cohort of Sixth Graders. Child Development, 78(4), 1186-1203. https://doi.org/10.1111/j.1467-8624.2007.01060.x

Kim, B., Lee, K. H., Xue, L., \& Niu, X. (2018). A review of dynamic network models with latent variables. Statistics surveys, 12, 105-135. https://doi.org/10.1214/18-SS121

Kim, J. (2015). How to choose the level of significance: A pedagogical note.

Kolleck, N. (2015). Uncovering influence through Social Network Analysis: the role of schools in Education for Sustainable Development. Journal of Education Policy, 31(3), 308-329. https:// doi.org/10.1080/02680939.2015.1119315

Kossinets, G. (2006). Effects of missing data in social networks. Social Networks, 28, 247-268. https://doi.org/10.1016/j.socnet.2005.07.002

Krivitsky, P. N., \& Goodreau, S. M. (2019). STERGM-Separable Temporal ERGMs for modeling discrete relational dynamics with statnet. https://cran.r-project.org/web/packages/tergm/vignettes/STERGM.pdf

Krivitsky, P. N., \& Handcock, M. S. (2014). A separable model for dynamic networks. Journal of the Royal Statistical Society: Series B (Statistical Methodology), 76(1), 29-46. https://doi. org/10.1111/rssb.12014

Krivitsky, P. N. (2012). Exponential-family random graph models for valued networks. Electronic journal of statistics, 6, 1100-1128. https://doi.org/10.1214/12-EJS696

Knoke, D., \& Yang, S. (2020). Social network analysis. SAGE.

Landherr, A., Friedl, B., \& Heidemann, J. (2010). A Critical Review of Centrality Measures in Social Networks. Business \& Information Systems Engineering, 2(6), 371-385. https://doi. org/10.1007/s12599-010-0127-3

Leung, B. P., \& Silberling, J. (2006). Using sociograms to identify social status in the classroom. The California School Psychologist, 11(1), 57-61. https://doi.org/10.1007/BF03341115

Levy (2016). gwdegree: Improving interpretation of geometrically-weighted degree estimates in exponential random graph models. Journal of Open Source Software, 1(3), 36, https://doi. org/10.21105/joss.00036

Li, Y., \& Carriere, K. C. (2013). Assessing goodness of fit of exponential random graph models. International Journal of Statistics and Probability, 2(4), 64. https://doi.org/10.5539/ijsp. $\mathrm{v} 2 \mathrm{n} 4 \mathrm{p} 64$

Lin, N. (2017). Building a Network Theory of Social Capital. Social Capital, 3-28. https://doi. org/10.4324/9781315129457-1

Lubbers, M. J. (2003). Group composition and network structure in school classes: a multilevel application of the p- model. Social Networks, 25(4), 309-332. https://doi.org/10.1016/ S0378-8733(03)00013-3

Lubbers, M. J., \& Snijders, T. A. (2007). A comparison of various approaches to the exponential random graph model: A reanalysis of 102 student networks in school classes. Social networks, 29(4), 489-507. https://doi.org/10.1016/j.socnet.2007.03.002

Lusher, D., Koskinen, J., \& Robins, G. (Eds.). (2012). Exponential Random Graph Models for Social Networks: Theory, Methods, and Applications (Structural Analysis in the Social Sciences). Cambridge University Press. https://doi.org/10.1017/CBO9780511894701

Martınez, A., Dimitriadis, Y., Rubia, B., Gómez, E., \& De La Fuente, P. (2003). Combining qualitative evaluation and social network analysis for the study of classroom social interactions. Computers \& Education, 41(4), 353-368. https://doi.org/10.1016/j.compedu.2003.06.001 
Meijs, C., \& De Laat, M. (2012). Social Network Analyses (SNA) as a method to study the structure of contacts within teams of a school for secondary education. In V. Hodgson, C. Jones, M. de Laat, D. McConnell, T. Ryberg, \& P. Sloep (Eds.), Proceedings of the 8th International Learning Conference on Networked Learning.

Moreno, J. L. (1934). Who shall survive?: A new approach to the problem of human interrelations. Nervous and Mental Disease Publishing Co. https://doi.org/10.1037/10648-000

Morris, M., Handcock, M. S., \& Hunter, D. R. (2008). Specification of exponential-family random graph models: terms and computational aspects. Journal of statistical software, 24(4), 1548-7660. https://doi.org/10.18637/jss.v024.i04

Morris, M., Krivitsky, P. N., Handcock, M. S., Butts, C. T., Hunter, D. R., Goodreau, S. M., \& Bender de-Moll, S. (2019). Temporal Exponential Random Graph Models (TERGMs) for dynamic network, modeling in statnet. http://statnet.org/tergm_tutorial.html

Mrvar, A., \& Batagelj, V. (2019). Programs for analysis and visualization of very large networks: Reference manual. http://mrvar.fdv.uni-lj.si/pajek/pajekman.pdf

Munoz, D. A., Queupil, J. P., \& Fraser, P. (2016). Assessing collaboration networks in educational research. International Journal of Educational Management, 30(3), 416-36. https://doi. org/10.1108/IJEM-11-2014-0154

Murphy, P. (2020). Phil Murphy Tutorials. https://rpubs.com/pjmurphy

Nagy, T., Nagyová, S., \& Szárazová, B. (2018). Sociometria v pedagogickom výskume. Biológia, Ekológia, Chémia, 22(4), 4-11.

Naim, K., Yuldashev, F., Demiroz, F., \& Arslan, T. (2010). Social network analysis (SNA) applications in evaluating MPA classes. Journal of Public Affairs Education, 16(4), 541-564. https://doi.org/10.1080/15236803.2010.12001614

Parkhurst, J. T., \& Hopmeyer, A. (1998). Sociometric popularity and peer-perceived popularity: Two distinct dimensions of peer status. The Journal of Early Adolescence, 18(2), 125-144. https://doi.org/10.1177/0272431698018002001

Peery, J. C. (1979). Popular, amiable, isolated, rejected: A reconceptualization of sociometric status in preschool children. Child Development, 50(4), 1231-1234. https://doi. org/10.2307/1129356

Quardokus, K., \& Henderson, C. (2015). Promoting instructional change: using social network analysis to understand the informal structure of academic departments. Higher Education, 70(3), 315-335. https://doi.org/10.1007/s10734-014-9831-0

Radford, M. (2008). Complexity and truth in educational research. Educational Philosophy and Theory, 40(1), 144-157. https://doi.org/10.1111/j.1469-5812.2007.00396.x

Ripley, R. M., Snijders, T. A., Boda, Z., Vörös, A., \& Preciado, P. (2020). Manual for SIENA version 4.0. University of Oxford.

Robins, G., Pattison, P., Kalish, Y., \& Lusher, D. (2007). An introduction to exponential random graph $\left(\mathrm{p}^{*}\right)$ models for social networks. Social networks, 29(2), 173-191. https://doi. org/10.1016/j.socnet.2006.08.002

Sabidussi, G. (1966). The centrality index of a graph. Psychometrika, 31(4), 581-603. https:// doi.org/10.1007/bf02289527

Sarkar, P., \& Moore, A. W. (2006). Dynamic social network analysis using latent space models. In Advances in Neural Information Processing Systems (s. 1145-1152). https://doi. org/10.1145/1117454.1117459

Schofield, J. W. \& Whitley, B. E. (1983). Peer Nomination vs. Rating Scale Measurement of Children's Peer Preferences. Social Psychology Quarterly, 46(3), 242-251. https://doi. org/10.2307/3033795 
Scott, J. (2012). What is social network analysis? Bloomsbury Academic.

Scott, J. (2017). Social network analysis (Fourth Edition). SAGE.

Sewell, D. K., \& Chen, Y. (2015). Latent space models for dynamic networks. Journal of the American Statistical Association, 110(512), 1646-1657. https://doi.org/10.1080/01621459.201 4.988214

Shibutani, T. (2000). Social processes: an introduction to sociology. iUniverse.com.

Snijders, T. A. (1996). Stochastic actor- oriented models for network change. Journal of mathematical sociology, 21(1-2), 149-172.https://doi.org/10.1080/0022250X.1996.9990178

Snijders, T. A., \& Baerveldt, C. (2003). A multilevel network study of the effects of delinquent behavior on friendship evolution. Journal of mathematical sociology, 27(2-3), 123-151. https:// doi.org/10.1080/00222500305892

Snijders, T. A., Pattison, P. E., Robins, G. L., \& Handcock, M. S. (2006). New specifications for exponential random graph models. Sociological methodology, 36(1), 99-153. https://doi. org/10.1111/j.1467-9531.2006.00176.x

Snijders, T. A., Van de Bunt, G. G., \& Steglich, C. E. (2010). Introduction to stochastic actor-based models for network dynamics. Social networks, 32(1), 44-60. https://doi. org/10.1016/j.socnet.2009.02.004

Steglich, C., Snijders, T. A. B., \& Pearson, M. (2010). 8. Dynamic Networks and Behavior: Separating Selection from Influence. Sociological Methodology, 40(1), 329-393. https://doi. org/10.1111/j.1467-9531.2010.01225.x

Stepanyan, K., Borau, K., \& Ullrich, C. (2010). A social network analysis perspective on student interaction within the twitter microblogging environment. In 2010 10th IEEE international conference on advanced learning technologies (s. 70-72). IEEE.

Sweet, T. M., Thomas, A. C., \& Junker, B. W. (2013). Hierarchical network models for education research: Hierarchical latent space models. Journal of Educational and Behavioral Statistics, 38(3), 295-318. https://doi.org/10.3102/1076998612458702

Šalamounová, Z., \& Fučík, P. (2019). The relationship between peer status and students' participation in classroom discourse. Educational Studies. https://doi.org/10.1080/0305569 8.2019.1706042

The Statnet Development Team (2019). An Example Analysis Using LOLOG. https://cran.rproject.org/web/packages/lolog/vignettes/lolog-ergm.pdf

Titmanová, M. (2019). Klima ve školní třídě aneb šikana v praxi. Školský psychológ/Školní psycholog, 20(1), 67-76.

UCINET. (2020). UCINET Software. https://sites.google.com/site/ucinetsoftware/

Valente, T. W., Coronges, K., Lakon, C., \& Costenbader, E. (2008). How Correlated Are Network Centrality Measures?. Connections, 28(1), 16-26.

Van Der Pol, J. (2017). Introduction to network modeling using Exponential Random Graph models (ERGM). https://hal.archives-ouvertes.fr/hal-01284994/document

Vítová, J., Balcarová, J., \& Linhartová, V. (2013). The social position of pupils with special educational needs in the group intact peers. Paidagogos - Journal of Education in Contexts, 2013(2), 451-464.

Wang, P., Robins, G., \& Pattison, P. (2009). PNet: program for the simulation and estimation of exponential random graph models. Melbourne School of Psychological Sciences, The University of Melbourne. 
Wang, P., Robins, G., Pattison, P., \& Lazega, E. (2013). Exponential random graph models for multilevel networks. Social Networks, 35(1), 96-115. https://doi.org/10.1016/j.socnet.2013.01.004

Wang, Y. J., \& Wong, G. Y. (1987). Stochastic blockmodels for directed graphs. Journal of the American Statistical Association, 82(397), 8-19. https://doi.org/10.1080/01621459.1987.1047 8385

Wasserman, S., \& Faust, K. (2019). Social network analysis: methods and applications. Cambridge University Press.

Wasserman, S., \& Pattison, P. (1996). Logit models and logistic regressions for social networks: I. An introduction to Markov graphs and p. Psychometrika, 61(3), 401-425. https://doi. org/10.1111/j.1469-7610.1994.tb01806.x10.1007/BF02294547

White, H. C. (2008). Identity and control: How social formations emerge. Princeton University Press.

Williams, B. T., \& Gilmour, J. D. (1994). Annotation: Sociometry and peer relationships. Journal of Child Psychology and Psychiatry, 35(6), 997-1013. https://doi.org/10.1111/j.1469-7610.1994. tb01806.x

\section{Kontakt na autora}

Tomáš Lintner

Ústav pedagogických věd, Filozofická fakulta, Masarykova univerzita

E-mail: tomas.lintner@mail.muni.cz

\section{Corresponding author}

\section{Tomáš Lintner}

Department of Educational Sciences, Faculty of Arts, Masaryk University

E-mail: tomas.lintner@mail.muni.cz 
